\title{
Harnessing Finger Millet to Combat Calcium Deficiency in Humans: Challenges and Prospects
}

\author{
Swati Puranik ${ }^{1}$, Jason Kam ${ }^{1}$, Pranav P. Sahu ${ }^{1}$, Rama Yadav ${ }^{1}$, Rakesh K. Srivastava ${ }^{2}$, \\ Henry Ojulong ${ }^{3}$ and Rattan Yadav ${ }^{1 *}$ \\ ${ }^{1}$ Institute of Biological, Environmental and Rural Sciences, Aberystwyth University, Aberystwyth, United Kingdom, \\ ${ }^{2}$ International Crops Research Institute for the Semi-Arid Tropics, Patancheru, India, ${ }^{3}$ International Crops Research \\ Institute for the Semi-Arid Tropics, Nairobi, Kenya
}

\section{OPEN ACCESS}

Edited by:

Raul Antonio Sperotto, Centro Universitário UNIVATES, Brazil

Reviewed by:

Sukhwinder Singh,

International Maize and Wheat Improvement Center, Mexico

Prashant Vikram,

International Maize and Wheat

Improvement Center, Mexico

Charu Lata,

National Botanical Research Institute

(CSIR), India

*Correspondence:

Rattan Yadav

rsy@aber.ac.uk

Specialty section:

This article was submitted to

Plant Nutrition,

a section of the journal

Frontiers in Plant Science

Received: 17 May 2017

Accepted: 12 July 2017

Published: 26 July 2017

Citation:

Puranik S, Kam J, Sahu PP, Yadav R,

Srivastava RK, Ojulong $H$ and Yadav $R$

(2017) Harnessing Finger Millet to

Combat Calcium Deficiency in

Humans: Challenges and Prospects.

Front. Plant Sci. 8:1311.

doi: 10.3389/fp/s.2017.01311
Humans require more than 20 mineral elements for healthy body function. Calcium (Ca), one of the essential macromineral, is required in relatively large quantities in the diet for maintaining a sound overall health. Young children, pregnant and nursing women in marginalized and poorest regions of the world, are at highest risk of Ca malnutrition. Elderly population is another group of people most commonly affected by Ca deficiency mainly in the form of osteoporosis and osteopenia. Improved dietary intake of Ca may be the most cost-effective way to meet such deficiencies. Finger millet [Eleusine coracana (L.) Gaertn.], a crop with inherently higher Ca content in its grain, is an excellent candidate for understanding genetic mechanisms associated with Ca accumulation in grain crops. Such knowledge will also contribute toward increasing Ca contents in other staple crops consumed on daily basis using plant-breeding (also known as biofortification) methods. However, developing Ca-biofortified finger millet to reach nutritional acceptability faces various challenges. These include identifying and translating the high grain Ca content to an adequately bioavailable form so as to have a positive impact on Ca malnutrition. In this review, we assess some recent advancements and challenges for enrichment of its Ca value and present possible inter-disciplinary prospects for advancing the actual impact of Ca-biofortified finger millet.

Keywords: finger millet, calcium, osteoporosis, bioavailability, food processing, biofortification, genetic improvement, plant breeding

\section{IMPORTANCE OF CALCIUM IN HUMAN DIET}

Calcium (Ca) is the fifth most abundant element present in the human body, accounting for up to $1.9 \%$ of the body weight in adults (Nordin, 1976). Its main functions are to provide rigidity and structure, mediating vascular and muscular contractions or dilations and nerve signal transmission (Institute of Medicine (US) Standing Committee on the Scientific Evaluation of Dietary Reference Intakes, 1997; Nordin, 1997). Ca may also serve in the protective role against various types of cancer viz. colorectal (Institute of Medicine (US) Committee to Review Dietary Reference Intakes for Vitamin D and Calcium, 2011), ovarian (Goodman et al., 2002), breast (Lin et al., 2007), and prostate (Gao et al., 2005). Although not supported by clinical trials, observational studies have associated higher $\mathrm{Ca}$ intakes to lower body weight and reduced adiposity, which may be due to lower intracellular $\mathrm{Ca}$ in fat cells leading to a higher fat breakdown (Parikh and Yanovski, 2003). Thus, it may reduce the risk of cardiovascular diseases by lowering intestinal lipid absorption, promoting lipid excretion and decreasing cholesterol concentrations in the blood 
(Institute of Medicine (US) Committee to Review Dietary Reference Intakes for Vitamin D and Calcium, 2011). Ca is also known to be important for those who have diabetes (Levy et al., 1994; Vestergaard, 2006; Pittas et al., 2007), particularly type 1 diabetics, who in general have lower bone mineral density than healthy subjects (Ma et al., 2012; Oei et al., 2013).

Given its importance, authorities like the Food and Agriculture Organization (FAO) of the United Nations have set up a recommended daily intake (RDI) of Ca based on age, life stage and gender (Food Agricultural Organization of the United Nations, 2002). During the phases of active growth, Ca equilibrium in the body maintains a stable bone mass. Therefore, FAO recommends that children of 1-3 years consume $500 \mathrm{mg}$ $\mathrm{Ca}$ /day, 4-6 years consume $600 \mathrm{mg} \mathrm{Ca} /$ day and 7-9 years consume $700 \mathrm{mg} \mathrm{Ca} /$ day, which should be increased to 1,300 mg/day during 10-18 years (Food Agricultural Organization of the United Nations, 2002). About $1,000 \mathrm{mg} \mathrm{Ca} /$ day is recommended between the ages of 19-65 years in males. The organization also advocates that women should take $1,000 \mathrm{mg}$ Ca each day from 19 years onwards until menopause raising it to $1,200 \mathrm{mg}$ during the last trimester of pregnancy, and to $1,300 \mathrm{mg}$ from 65 years and above (Food Agricultural Organization of the United Nations, 2002).

However, after 50 years in men and in menopausal women, the onset of bone decalcification and demineralization leads to reductions in bone mass causing the disease osteoporosis (Michaelsson et al., 2005). According to International Osteoporosis Foundation, it is a significant problem both in the developed as well as in developing nations (http:// www.iofbonehealth.org/facts-statistics). The World Health Organization (WHO) has declared osteoporosis as the next main public healthcare concern globally, after cardiovascular diseases (CVDs), inflicting almost 75 million people in Europe, the United States of America and Japan alone (Consensus Development Statement, 1997; Haldipur, 2003). With a growing elderly population, osteoporosis is threatening to become a major global economic burden for the already stretched healthcare system across the globe. By 2050, the worldwide cost of treating osteoporosis is forecasted to USD 131.5 billion (Lindsay et al., 2001). Thus, in order to prevent Ca deficiency at this age, it is necessary to sustain the recommended daily intake (RDI) of 1,300 mg/day (especially after 65 years; Food Agricultural Organization of the United Nations, 2002) to ensure maximal bone mass during the developmental stages and to have reduced bone mass loss during old age (Michaelsson, 2009).

Despite the importance of adequate $\mathrm{Ca}$ intake for human health and wellbeing, the WHO estimates that low dietary intake of $\mathrm{Ca}$ is common across the world (WHO, 2006). On a global scale, it presents a large risk which gets graver in underdeveloped regions of the world. However, the absence of reliable and practical indicators in these areas provides insufficient data, which is a challenge for resolving the actual global status for the prevalence of Ca deficiency. It has recently been determined (mainly based on food supply) that 3.5 billion people were at the risk of $\mathrm{Ca}$ deficiency in 2011, with approximately $90 \%$ of the affected individuals in Africa and Asia (Kumssa et al., 2015). Most of these regions have an agriculture-based economy and large segments of these populations are typically dependent on what they grow and produce for their $\mathrm{Ca}$ need. In such situations, staple crops that can offer adequate Ca requirements, especially for people of low income groups in these countries, are highly recommended. One such Ca-rich, traditional and locally well-adapted crop is finger millet. As opposed to nutritionally deficient cereals, such as rice, its regular consumption has a vast potential to curb the incidences of $\mathrm{Ca}$ deficiency. Finger millet also possesses many other health-benefitting traits. For example, it has been highlighted that as a model nutraceutical crop, finger millet can provide excellent solutions to food and health security issues (Kumar et al., 2016a). Being a stress resilient crop requiring minimal inputs for growth it is especially suited for sustainable agriculture (Gupta et al., 2017). Despite this, it has received very little scientific attention, relative to other crops, such as rice, wheat and maize. Some very recent reviews have provided a comprehensive account of molecular mechanisms that may be involved in calcium nutrition in finger millet and how various approaches, including molecular breeding, functional genomics and transgenic technology can elevate Ca accumulation in its grains (Ganapathy, 2017; Sharma et al., 2017). However, beyond this, in order to advance biofortification of finger millet, challenges associated with its impact on human health also needs to be critically evaluated. With this as focus, we have not only attempted to highlight its potential but also the prospects of advancing the bioaccessibility of grain Ca content even further.

\section{STRATEGIES TO PREVENT CALCIUM DEFICIENCY}

Calcium (Ca) deficiency is almost physically undetectable and difficult to diagnose during preliminary stages (Wang et al., 2013), however, if detected, it is usually easy to treat by increasing dietary $\mathrm{Ca}$ intake or absorption. Currently, there are many strategies that can be undertaken to manage the problem of $\mathrm{Ca}$ deficiency. These mainly include diversification of diet, food fortification, external supplementation and crop biofortification.

Dietary changes by including foods that are naturally rich in $\mathrm{Ca}$, like dairy products, seems to be the most efficient way to prevent Ca deficiency. However, it is not easy to persuade people to go for diversified diets and certain foods cannot be included in the diets. For example, $65 \%$ of the world's population is lactoseintolerant and therefore they cannot rely on dairy products for their Ca requirement. Incidentally, most of these lactoseintolerant people live in Asian and African regions (Curry, 2013), which are predominantly dependent on agriculturebased economies. Additionally, due to resource constrain, they may not be able to afford livestock or may solely raise cattle for supplementing income and deny themselves of milk and milk products. Therefore, many communities in these regions, including vegetarians and vegans, need alternative sources to meet their Ca needs.

Another strategy can be an industry-based fortification of foods consumed by target groups. For example, policy decisions in the western world have supported fortification of breakfast cereals, fruit juices, flours and sports drinks with Ca. However, 
fortification may alter flavor, bioavailability, shelf life or safety of the product, thus making it unpalatable to the consumers. Further, consumers in under-developed nations, with limited education and economic resources, often do not always have access to such fortified foods.

Supplementation is an alternative in which Ca tablets are used to prevent $\mathrm{Ca}$ deficiency. Although more accessible to people, this strategy suffers from major drawbacks, mostly associated with their side-effects (Institute of Medicine (US) Committee to Review Dietary Reference Intakes for Vitamin D and Calcium, 2011). The most common content of supplementation pills are the inorganic forms: calcium carbonate and calcium citrate. Large amounts of Ca supplements cause excessive $\mathrm{Ca}$ accumulation in vascular and soft tissues like arteries or organs, such as kidneys which can lead to heart attack or kidney stones, respectively (Bolland et al., 2010; Institute of Medicine (US) Committee to Review Dietary Reference Intakes for Vitamin D and Calcium, 2011). Some studies have also linked supplement intake with higher risk of breast cancer, prostate cancer and cardiovascular diseases (Institute of Medicine (US) Committee to Review Dietary Reference Intakes for Vitamin D and Calcium, 2011). Further, taking Ca supplements with meals may also reduce absorption of other minerals like zinc and iron (Cook et al., 1991). Therefore, even though this strategy can potentially reach many people, the associated medical problems make it a non-viable long-term option.

To combat $\mathrm{Ca}$ deficiency for a wider and more sustainable impact, alternative solutions that are cost-effective and can easily be adopted especially in the developing countries settings need to be pursued. Genetic biofortification is one such very powerful plant breeding or transgenics-based strategy which can combat the global challenge of micronutrient deficiency (www.copenhagenconsensus.com). As it involves the already established agricultural systems to grow, breed and distribute nutrient-dense staple crops, it can be the most economically and socially feasible approach to integrate nutrition into the diets of the impoverished. Biofortified staple crops have been quantified to have high potential benefits and cost effectiveness as their cost per disability-adjusted life years (DALYs) saved is less than the national per capita income, when compared to other interventions, such as fortification and supplementation (Stein et al., 2005; Asare-Marfo et al., 2014).

Over the last decade several projects, such as those initiated by Harvest Plus, have released nutritionally enhanced rice and wheat varieties (Bouis et al., 2011). Recently, efforts have also commenced for biofortification breeding of small cereals, such as millets. Miles ahead of widely consumed rice and wheat, this group of hardy cereals contribute up to $75 \%$ of the total calorie intake for poorest of the poor (O’Kennedy et al., 2006). Therefore, millets hold stronger promise to provide economic, food and nutritional security to people surviving on marginal and resource-poor soils (Muthamilarasan et al., 2016). In this respect, pearl millet has become a target for biofortification of iron and zinc (Manwaring et al., 2016) and has entered the spotlight in combating diabetes (Kam et al., 2016). Similarly, finger millet is also gaining popularity as an ideal target crop for Ca biofortification.

\section{WHY USE FINGER MILLET AS A MODEL FOR CALCIUM BIOFORTIFICATION?}

Finger millet possesses all the quantitative and qualitative traits to serve as a model for Ca biofortification. It stands out as the richest source of $\mathrm{Ca}$ among all the cereals (Table 1 ). It has three times more $\mathrm{Ca}$ than milk and 10-fold higher $\mathrm{Ca}$ than brown rice, wheat or maize (Kumar et al., 2016a). Besides Ca, finger millet is also very rich source of iron, amino acids like methionine, slowly digestible starch and phytochemicals like polyphenols. It is a gluten-free, low fat cereal which is non-allergic and easily digestible. For these characteristics, it is often termed as a "super cereal" (Kumar et al., 2016a). Apart from its nutritional attributes, finger millet has excellent environmental sustainability credentials. It can easily withstand harsh climatic conditions, low soil fertility, requires very little inputs with a short growing season (Kumar et al., 2016a). It can reach the yield potential of up to 10 tons/ha under optimum irrigated conditions (Padulosi et al., 2015). It has excellent storage quality traits and can be valuable in areas where farmers suffer losses due to dearth of post-harvest management.

Therefore, integration of a naturally Ca-rich crop like finger millet in global biofortification programs can be a good starting point to alleviate Ca malnutrition (Sharma et al., 2017). Given that women share a significantly higher proportion of osteoporotic morbidity ("Facts and Statistics," International Osteoporosis Foundation, http://www.iofbonehealth.org/factsstatistics), regular consumption of finger millet during and after pregnancy as well as lactation can provide significant benefits to maternal and child bone health. Another advantage of Ca-enriched finger millet over expensive commercially fortified foods is its affordability to these malnourished areas. For lowincome households which mostly subsist on starchy and bulky foods like rice and cassava for their calorie requirements (https:// www.devex.com/news/better-crops-for-better-nutrition-86583), finger millet ensures a pragmatic solution that no family member (especially women and children) suffers from Ca deficiency.

\section{PROSPECTING BIOAVAILABILITY OF CALCIUM FROM BIOFORTIFIED FINGER MILLET TO ACHIEVE ADEQUATE INTAKES}

Determining the efficacy and biological impact of Ca-biofortified finger millet on better nutrition and improved health is very challenging. It depends mainly on two processes: bioaccessibility and bioavailability of $\mathrm{Ca}$ in the seeds. Bioaccessibility is a measure of the nutrient fraction available for absorption after its release from food matrix in the gastrointestinal tract. On the other hand, bioavailability is a utilization-based definition, where the ingested, digested and absorbed nutrient reaches the systemic circulation and exerts a positive effect on health (CarbonellCapella et al., 2014). Solubility, dialysability and gastrointestinal model are generally used as in vitro methods for measuring $\mathrm{Ca}$ bioaccessibility. On the other hand, evaluation of $\mathrm{Ca}$ bioavailability is ideally evaluated through in vivo human studies. However, considering the complexity of large-scale human 
TABLE 1 | Calcium content of various cereals.

\begin{tabular}{|c|c|c|}
\hline Cereal & $\begin{array}{c}\text { Calcium content } \\
\text { (mg/100 g edible portion) }\end{array}$ & References \\
\hline \multicolumn{3}{|l|}{ MILLETS } \\
\hline $\begin{array}{l}\text { Finger millet (Eleusine } \\
\text { coracana L.) }\end{array}$ & 344 & Shobana et al., 2013 \\
\hline $\begin{array}{l}\text { Teff (Eragrostis teff), } \\
\text { mixed }\end{array}$ & $78.8-147$ & Baye, 2014 \\
\hline Fonio (Digitaria exilis) & 44 & $\begin{array}{l}\text { National Research } \\
\text { Council, } 1996\end{array}$ \\
\hline $\begin{array}{l}\text { Pearl millet } \\
\text { (Pennisetum glaucum) }\end{array}$ & 42 & Shobana et al., 2013 \\
\hline $\begin{array}{l}\text { Foxtail millet (Setaria } \\
\text { italica) }\end{array}$ & 31 & Shobana et al., 2013 \\
\hline $\begin{array}{l}\text { Kodo millet (Paspalum } \\
\text { scrobiculatum) }\end{array}$ & 27 & Shobana et al., 2013 \\
\hline $\begin{array}{l}\text { Barnyard millet } \\
\text { (Echinochloa crus-galli) }\end{array}$ & 20 & Shobana et al., 2013 \\
\hline $\begin{array}{l}\text { Little millet (Panicum } \\
\text { sumatrense) }\end{array}$ & 17 & Shobana et al., 2013 \\
\hline $\begin{array}{l}\text { Proso millet (Panicum } \\
\text { miliaceum) }\end{array}$ & 14 & Shobana et al., 2013 \\
\hline \multicolumn{3}{|l|}{ COMMON CEREALS } \\
\hline $\begin{array}{l}\text { Wheat (Triticum } \\
\text { aestivum) }\end{array}$ & 41 & Shobana et al., 2013 \\
\hline $\begin{array}{l}\text { Rice (Oryza sativa) } \\
\text { brown }\end{array}$ & 33 & Saleh et al., 2013 \\
\hline Corn (Zea mays) & 26 & Saleh et al., 2013 \\
\hline $\begin{array}{l}\text { Sorghum (Sorghum } \\
\text { bicolor) }\end{array}$ & 25 & Saleh et al., 2013 \\
\hline $\begin{array}{l}\text { Barley (Hordeum } \\
\text { vulgare), raw }\end{array}$ & 20 & McKevith, 2004 \\
\hline $\begin{array}{l}\text { Rye (Secale cereale), } \\
\text { flour }\end{array}$ & 20 & McKevith, 2004 \\
\hline $\begin{array}{l}\text { Oatmeal (Avena sativa), } \\
\text { quick cook raw }\end{array}$ & 52 & McKevith, 2004 \\
\hline $\begin{array}{l}\text { Rice (Oryza sativa) raw } \\
\text { milled }\end{array}$ & 10 & Shobana et al., 2013 \\
\hline
\end{tabular}

trials and ethico-legal procedures, Caco-2 cell culture, which behave like human intestinal cells, can provide an alternative analysis.

It is well known that only $<30 \%$ of the consumed $\mathrm{Ca}$ is effectively absorbed (Heaney, 2006). Interestingly, using the in vitro bioaccessibility methods, uncooked finger millet has been found to have $36.6 \%$ soluble and $28 \%$ dialyzable and bioavailable $\mathrm{Ca}$ (Amalraj and Pius, 2015). This is higher than rice $(30.4 \%$ soluble Ca; $24.7 \%$ dialyzable $\mathrm{Ca}$ ), sorghum (31.9\% soluble Ca; $26.0 \%$ dialyzable $\mathrm{Ca}$ ) and maize (25.4\% dialyzable $\mathrm{Ca})$. Therefore, finger millet in itself is an effective source of bioavailable $\mathrm{Ca}$ than many other staple cereals and its improvement through biofortification is an effective strategy that can relegate $\mathrm{Ca}$ deficiency.

However, the fate of actual Ca bioavailability from finger millet relies on and is challenged by several other factors. These include intrinsic grain property (solubility, interaction with other constituents of the food matrix) and extrinsic factors (condition of the host, food processing and storage). Therefore, a better understanding of how these factors influence and impact $\mathrm{Ca}$ efficacy becomes essential before the biofortified finger millet can carve a path in the farmer and consumer markets.

\section{Grain's Intrinsic Factors That Impact Ca Bioavailability in Finger Millet}

Many plant-based Ca sources have limited accessibility of Ca for absorption due to the formation of insoluble complexes. Phytate and oxalate are two such bioavailability limiters that can impede $\mathrm{Ca}$ absorption as they exhibit a strong negative correlation with Ca bioaccessibility (Kamchan et al., 2004; Gibson et al., 2010; Krishnan et al., 2012). Several studies in legumes and cruciferous vegetables have reported that high in vitro $\mathrm{Ca}$ solubility and dialysability corresponds to low levels of phytate, oxalate and dietary fiber (Lucarini et al., 1999; Kamchan et al., 2004). In cereals, phytate and oxalate were shown to account for 7 and 15-20\% inhibition of Ca bioavailability, respectively (Amalraj and Anitha Pius, 2015). In wheat and barley, phytate, but not fiber, has been proclaimed as having the major inhibitory effect on Ca absorption (Kennefick and Cashman, 2000). Phenolic compounds like tannins reduce the bioavailability of minerals by forming insoluble complexes with divalent metal ions (Rao and Prabavathi, 1982). An in vivo digestibility trial on birds fed on low (1\%), medium (2\%), and high (3\%) tannin sorghum diets showed that as compared to control, the Ca absorption reduced by 1.22 , 1.67 and 2.22 fold, respectively (Mahmood et al., 2014).

Likewise, finger millet also contains these antinutrients that negatively affect grain palatability and can be a constraint to its Ca bioaccessibility. There is a wide range of phytate and oxalate content in finger millet based on the genotypes. The phytate content in finger millet ranges from $679 \mathrm{mg} / 100 \mathrm{~g}$ to 1,419.4 mg/100 g (Antony and Chandra, 1999; Makokha et al., 2002). The grains have been found to contain higher phytate content $(783.5 \mathrm{mg} / 100 \mathrm{~g})$ than rice $(289.9 \mathrm{mg} / 100 \mathrm{~g})$, pearl millet $(518.5 \mathrm{mg} / 100 \mathrm{~g})$ and sorghum $(571.1 \mathrm{mg} / 100 \mathrm{~g})$ but lower than wheat $(792.1 \mathrm{mg} / 100 \mathrm{~g}$ ) and maize $(851.5 \mathrm{mg} / 100 \mathrm{~g})$ (Amalraj and Pius, 2015). Similarly, finger millet grains have been reported to contain oxalic acid to the extent of $45.7 \mathrm{mg} / 100 \mathrm{~g}$ (Rachic and Peters, 1977). Out of the total oxalate fraction present in the food matrix, soluble oxalate has the ability to bind $\mathrm{Ca}$ and reduce its absorption. In a recent study, it was found that finger millet has higher total oxalate content $(11.3 \mathrm{mg} / 100 \mathrm{~g})$ than other cereals (except pearl millet; $20.0 \mathrm{mg} / 100 \mathrm{~g}$ ) but had the lowest percentage of soluble oxalate $(45.9 \%)$ among other cereals (Amalraj and Pius, 2015). Even though the phytate and total oxalate content of finger millet are higher than many other cereals, it still contains more bioavailable Ca percentage (28\%) than rice $(24.7 \%)$, maize (25.4\%), and sorghum (26\%) (Amalraj and Pius, 2015).

Finger millet grains also have a wide range of total phenolics and tannins content (Devi et al., 2014). Tannin content estimation has revealed that the African varieties of finger millet have about three times more tannin percent than the Indian varieties (Ramachandra et al., 1977). Finger millet has been shown to contain up to $264.1 \mathrm{mg} / 100 \mathrm{~g}$ tannin (Amalraj and Pius, 2015). This is much higher than maize $(25.5 \mathrm{mg} / 100 \mathrm{~g})$ and rice 
( $14.3 \mathrm{mg} / 100 \mathrm{~g})$ but lower than pearl millet $(275.8 \mathrm{mg} / 100 \mathrm{~g})$ and wheat $(287.3 \mathrm{mg} / 100 \mathrm{~g})$ (Amalraj and Pius, 2015). Despite the knowledge of the extent of varietal variations in tannin content of finger millet, their direct effect on inhibition of $\mathrm{Ca}$ absorption and bioavailability has yet not been investigated.

Calcium absorption may also be affected by the non-digestible oligosaccharides and dietary fibers in the food matrix. These compounds reduce the activity of digestive enzymes and slow down the digestion process. Dietary fibers were found to be significantly associated to Ca bioavailability in commercially available rice flakes (Suma et al., 2007). The indigestible starch component (resistant starch) has been found to increase Ca absorption in rats, probably by enhancing its solubility (Schulz et al., 1993). Finger millet is also a great source of resistant starch (Devi et al., 2014). It also has the highest total, soluble and insoluble dietary fiber when compared with wheat, rice, maize, sorghum and pearl millet (Amalraj and Pius, 2015). The role of such factors present in finger millet and other grain crops is generally considered positive in Ca absorption but the magnitude of their stimulatory effect requires further validation by in vitro or in vivo methods.

For enhanced Ca bioavailability from finger millet, grain Ca content needs to be improved with a concomitant but conscious effort for the reduction of antinutrient compounds. This is because these compounds play a vital role in plant development and survival. For example, finger millet tannins are effective in reducing pre- and post-harvest losses as they provide protection against molds, insects and other abiotic stress (Gull et al., 2014). Similarly, phytic acid acts as the main phosphorus store for the seeds (Singh and Raghuvanshi, 2012). These compounds have also called attention due to their nutraceutical value and protective effects against many chronic diseases (Kumar et al., 2016a). Thus, their importance can never be completely disregarded. Engineering their content to become a non-limiting factor in Ca absorption from finger millet must be done in a way that does not negatively affect crop performance. A justified way to accomplish this is by employing efficient and suitable grain processing techniques.

\section{Influence of Grain Processing on Ca Bioavailability}

Processing techniques of the grain can affect the total mineral content and factors associated with their bioaccessibility. Finger millet is a very versatile cereal and can be processed and utilized in numerous ways while retaining the available Ca. Popping by high temperature and short time (HTST) treatment was found to have no effects on the total $\mathrm{Ca}$ content in finger millet but lowered the Ca bioaccessibility and polyphenol content by as much as 19 and 22\%, respectively (Krishnan et al., 2012). Microwave cooking by boiling also does not greatly improve the percentage of soluble or bioavailable $\mathrm{Ca}$ (Amalraj and Pius, 2015). This implies that HTST-based processing and microwave cooking methods do not favor improved bioaccessible $\mathrm{Ca}$ from finger millet.

On the other hand, sprouting of finger millet improves the extractability of $\mathrm{Ca}$ and lowers antinutrients like phytate and tannins to an undetectable level after 4 days (Mbithi-Mwikya et al., 2000). Flour made from whole grain finger millet was found to have higher Ca content $(325 \mathrm{mg} / 100 \mathrm{~g})$ than those made from decorticated $(222 \mathrm{mg} / 100 \mathrm{~g})$ one (Hemanalini et al., 1980). Decortication is a process of removal of the seed coat matter which is responsible for lowering Ca bioaccessibility. It is interesting to note that processing by decortication significantly improved Ca bioavailability in rats and this was attributed to its low fiber and phytic acid content (Hemanalini et al., 1980). In an evaluation of various processing methods of finger millet on Ca bioaccessibility, seed decortication and malting were found to be the most efficient techniques (Krishnan et al., 2012). Decortication improves Ca bioaccessibility by $37.5 \%$, in spite of lowering the total Ca content by $40 \%$. This increase was attributed to a direct decrease in inhibitory contents present in the seed coat like phytic acid (31\% reduction) and polyphenols (70\% reduction). Malting, which involves germination and thermal treatment, also influences the bioaccessible Ca content of finger millet in a positive way (Platel et al., 2010; Krishnan et al., 2012). Again, this is because germination process greatly reduces the concentration of phytic acid and polyphenols. Fermented flour or sprouting followed by fermentation also showed marked enhancement in Ca availability (20\%) with a concomitant decline in phytates, phenols, tannins, and trypsin inhibitor activity (Sripriya et al., 1997; Antony and Chandra, 1998; Makokha et al., 2002).

The above examples establish beyond doubt that bioaccessibility of $\mathrm{Ca}$ from finger millet can be even further improved by simple processing methods which can be scaled up to industrial levels. These methods have potential to add values to both traditional as well as to contemporary value-added food products improving their edible and sensory properties (Hotz and Gibson, 2007; Shobana et al., 2013; Verma and Patel, 2013).

\section{Host (Extrinsic) Factors That Influence Ca Bioavailability}

Apart from the Ca bioavailability parameters, the capability to determine the effect on Ca status on target populations is another specific challenge. Host factors, such as age, gender, dietary patterns may show differential effects of finger millet-based diets on the net Ca contribution. These factors must be considered in controlled feeding community-based studies to determining the biological impact of biofortified crops.

In the past, various attempts have been put together to assess the Ca bioavailability in vivo. Early nutrition studies have shown that rats fed with a diet composed of $70 \%$ finger millet retain $68 \%$ Ca (Giri, 1940). A further reduction of the finger millet content to $20-40 \%$ in diets contributed to increased Ca retention to $84-88 \%$ levels (Giri, 1940). This shows that even a low dietary component of finger millet is sufficient to maintain Ca availability because of its high Ca content. In fact, in a more recent study, $\mathrm{Ca}$ from finger millet had shown to have a better uptake as compared to commercial Ca supplementation tablet (Bhide et al., 2013). In this in vivo study, the serum Ca level of rats fed with finger millet extract and a finger millet based ready-to-drink formulation was $>35 \%$ higher as compared to conventional $\mathrm{Ca}$ tablet supplemented group. 
However, for human metabolism studies, host factors like age and gender are important parameters to estimate daily requirement, intake and retention of dietary $\mathrm{Ca}$. Many nutrition reports have estimated the contribution of finger millet for $\mathrm{Ca}$ homeostasis in humans. A study by Subrahmanyan et al. (1955) had found that a finger millet variety, $\mathrm{H} 22$, with $\mathrm{Ca}$ content $440 \mathrm{mg} / 100 \mathrm{~g}$ can on an average provide $3.4 \mathrm{~g} \mathrm{Ca} /$ day to healthy adult males aged 22-32 years. This amounted to Ca retention of $98 \mathrm{mg}$ (approximately 3\%) from a total daily intake of $3.4 \mathrm{~g} /$ day. This was higher than a brown bread or Ca carbonate fortified brown bread diet providing only $0.5-1.2 \mathrm{~g} \mathrm{Ca} /$ day, respectively (McCance and Widdowson, 1942). It is recommended that diets should provide at least $200 \mathrm{mg} / 100 \mathrm{~g}$ of $\mathrm{Ca}$ to counteract the anticalcifying effect of phytic acid (McCance and Widdowson, 1942). Interestingly, $86 \%$ of phytate ingested from the fingermillet-based diet was hydrolysed during digestion and absorption process (Subrahmanyan et al., 1955). As most of the phytate is broken down during digestion, therefore, regular inclusion of finger millet in diet can efficiently maintain a positive $\mathrm{Ca}$ balance. In another study, young girls (aged 9-10) were fed on four different diets containing only rice, $75 \%$ rice $+25 \%$ finger millet, $50 \%$ rice $+50 \%$ finger millet and only finger millet as the primary cereal (Joseph et al., 1959). About 19\% Ca was retained from just rice-based diets which increased to 22.5$25.3 \%$ when a portion of rice was replaced with $25-50 \%$ finger millet. Therefore, finger millet can naturally contribute to boost the Ca status across ages evidently surpassing the other cereals. One serving of finger millet-based Ca-rich products, which were processed to increase $\mathrm{Ca}$ bioavailability, was shown to provide $>0.2 \mathrm{~g}$ Ca contributing to $25 \%$ of Indian RDA of Ca for children and adolescents (Sanwalka et al., 2011). It is interesting to note that the Ca retention capacity of children seems to be much higher than adult subjects. This may be because growing age lowers digestibility and retention capacity of $\mathrm{Ca}$ and hydrolysis of antinutrients like phytate (Yoshida et al., 1983). It needs to be stressed here that most of these studies have been conducted more than 50 years ago. However, lifestyle and dietary patterns have drastically changed in recent years. Therefore, evaluating positive Ca impacts of finger millet diet across various groups needs to be measured keeping in view the current scenarios as well.

In a case study in rural India, the dietary patterns of women self-help groups was assessed for their nutrient adequacy (Vijayalakshmi et al., 2010). The families usually consumed one portion of finger millet preparation two times a day along with one portion of pulses and vegetables. It was found that irrespective of the socio-demographic profile of the subjects (like age, education, family income, family size), Ca levels met the recommended RDA and their adequacy was attributed to regular finger millet inclusive diet. As no major replacement of diet is necessary, finger millet and its derived food products have the advantage to be more acceptable to the people. This makes it a more viable option to be effective providing adequate $\mathrm{Ca}$ intakes and prevent $\mathrm{Ca}$ deficiency. These reports provide an idea that designing food products from biofortified varieties of finger millet can easily supplement and add-on to the daily $\mathrm{Ca}$ intake across ages and genders with various dietary practices.
Such information can allow the acceleration of finger millet biofortification programs.

\section{MAJOR CHALLENGES TO DEVELOP FINGER MILLET AS A MODEL FOR CALCIUM BIOFORTIFICATION}

In order to develop Ca biofortified finger millet, nutritionists must have available resources (superior Ca-rich varieties), a welldeveloped methodology to evaluate the bioaccessibility (in vitro and in vivo), awareness of the limiting factors (enhancers and inhibitors), and prior assessment of efficacy and effectiveness of Ca biofortified food. However, currently the development in this area is extremely limited and developing more nutritious varieties is challenging. Given that millet biofortification has recently been strategized, development of research programs for Ca-biofortified finger millet will have to address some arguments as discussed below.

\section{Challenges to Efficiently Utilize the Available Germplasm Resources and Genetic Diversity}

In recent years, various efforts have been made by geneticists and breeders to identify naturally occurring genetic diversity in finger millet. However, the major challenge at present is how these resources could be exploited to develop Ca-biofortified finger millet. Currently, finger millet genebanks across the globe conserve more than 37,000 accessions with India, Kenya, Ethiopia, Uganda, and Zambia housing the major collections (Vetriventhan et al., 2015). As of now, the entire genetic diversity present among the finger millet germplasm is available as small sets (core) and sub-sets (mini core) collections (Vetriventhan et al., 2015). Using these collections, 15 accessions were identified as most promising $(3.86-4.89 \mathrm{~g} / \mathrm{kg}$ ) for further improving grain Ca content in cultivated finger millet (Upadhyaya et al., 2011). Recently, another core set of 77 germplasm of Indian and African origin has been formed using the base germplasm of finger millet 1,000 accessions (Chandrashekhar et al., 2012). In addition, finger millet composite collections (1,000 accessions) and a derived reference set (300 accessions) representing regionand race-based available diversity of the entire collection, is also available (Upadhyaya et al., 2005; Upadhyaya, 2008). Although, these large collections of finger millet germplasm serve as an ideal resource to be utilized in improving its $\mathrm{Ca}$ concentration, a majority of it remains largely underutilized for breeding high $\mathrm{Ca}$ finger millet varieties. Some of the main reasons for this lag are due to factors, such as weak and insufficient strategies for harnessing the useful genetic diversity available in these collections, barriers related to introduction and crossing of exotic germplasm, few pre-breeding programs to facilitate introgression of desirable nutrition quality into breeding lines and recirculation of same working collections by breeders (Dwivedi et al., 2009; Upadhyaya et al., 2014). Although such precious germplasm collections exist, sometimes there are also practical barriers associated with their availability for use. For example, restricted global exchange of accessions due to legal aspects of 
seed transfer agreements poses a limitation for verification of adaptability to multi-location or multi-environment trials (Nass et al., 2012). Even a dearth of trained finger millet breeders to meet the demand can be an issue for making use of this treasure.

In addition, a huge range of diversity for grain $\mathrm{Ca}$ also exists within the gene pool of finger millet which remains to be exploited in targeted breeding. Two main gene pools exist for this species, namely Eleusine coracana sub-species africana (wild progenitor) and E. coracana sub-species coracana (domesticated cultivars/varieties and landraces (Agarwal and Maheshwari, 2016). Considerable variation in grain Ca contents has been observed in both the genepools. A detailed systematic analysis of grain Ca content in E. coracana sub species africana, from Ethiopia, revealed significantly higher Ca $(515 \mathrm{mg} / 100 \mathrm{~g})$ than the domesticated E. coracana sub species coracana from Kenya $(401 \mathrm{mg} / 100 \mathrm{~g})$ and India $(375 \mathrm{mg} / 100 \mathrm{~g})$ (Barbeau and Hilu, 1993). Many pieces of evidence for genotype effect in finger millet Ca content also exist. Vadivoo et al. (1998) found a large heritable genetic variation in relation to Ca content in 36 genotypes of finger millet, with white seeded varieties containing moderate levels of Ca. Based on their results, Malawi 1915 (486.7 mg/100 g Ca) and CO $11(487 \mathrm{mg} / 100 \mathrm{~g} \mathrm{Ca})$ genotypes were proposed to be employed as crossing parents in breeding for the improvement of Ca content. Similarly, the dark red to very dusty red colored finger millet genotypes, CO 10, KM 1 and MI 302 sourced from the Dry zone Agricultural Research Station, Sri Lanka were shown to contain 240-250 mg\% Ca (Ravindran, 1991). In another report, the white seeded finger millet varieties showed higher average $\mathrm{Ca}(329 \mathrm{mg} \%)$ than the brown seeded ones (296 mg\%) (Seetharam, 2001). In spite of the extensive screening of finger millet germplasm for grain Ca content, the identified potential candidate genotypes have remained unused for developing higher Ca containing varieties breeding.

At the same time, just selecting suitable donor lines for selective breeding based on variation in grain Ca content is not sufficient and may not even be successful as such variations may often be regulated at various other levels. Therefore, determination of genetic stability and adaptability of this trait across multiple environments is one of the prerequisite to develop effective strategies for breeding elite lines. However, a severe gap exists in our knowledge about accuracy by which genetic variation for $\mathrm{Ca}$ content can be reproduced by finger millet genotypes grown across various agro-ecological conditions.

\section{Challenges Associated with Breeding-Based Genetic Improvement of Finger Millet}

As finger millet is a naturally self-pollinating crop, artificial hybridisation by crossing of suitable parental lines is often a difficult task. Mass and pure-line selection practices have come in handy for inter-varietal improvement for grain yield, early maturity and disease resistance (Harinarayana, 1986; Table 2). For example, using pure line selection from the germplasm accession, finger millet culture WWN-25 has been released as a high yielding variety, GNN-7, for cultivation in
Gujrat state of India (Patil et al., 2016). This is a promising development as this variety contains higher $\mathrm{Ca}(468.0 \mathrm{mg} / 100 \mathrm{~g})$ than the national check variety VR-708 $(398.0 \mathrm{mg} / 100 \mathrm{~g})$ without compromising on the yield. However, optimum deployment of other breeding methods, such as recombination breeding, for generating stable hybrids, breeding progeny and inbred lines has been delayed due to challenging biparental cross, difficult emasculation and artificial hybridization in finger millet. To overcome these challenges, induced mutations, such as genetic male sterile systems (viz., INFM 95001 reported by ICRISAT; http://oar.icrisat.org/618/1/PMD_71.pdf) have proved to be another efficient breeding tool for yield and disease resistance in finger millet. These systems and their subsequent breeding can be used effectively to increase the genetic variance by creating new recombinants and segregating populations by exploiting the genetic background. Therefore, developing genetic resources for finger millet, such as mapping populations, breeding lines and male-sterile mutant lines (Gupta et al., 1997; Krishnappa et al., 2009; Parashuram et al., 2011), deserves attention. Such material will be immensely valuable for tagging nutritional quality traits, especially grain $\mathrm{Ca}$ content, and thus facilitate genetic biofortification of finger millet.

\section{Underutilization of Available Genetic and Genomic Resources for Molecular Breeding Applications}

Efforts have been made to generate molecular markers for characterizing important traits like grain $\mathrm{Ca}$ and protein content and resistance to blast infection in finger millet. Genomic tools like SSR markers have helped to assess the range of genetic diversity for grain $\mathrm{Ca}$ content in various finger millet genotypes (Panwar et al., 2010; Nirgude et al., 2014; Yadav et al., 2014; Kumar et al., 2015a). Nine SSR markers derived from candidate $\mathrm{Ca}$ transporter and sensor genes have been found to be significantly associated with the $\mathrm{Ca}$ trait. They could serve as an important functional resource for the genetic improvement of finger millet's nutritional value through markerassisted breeding (MAB; Kumar et al., 2015a; Sharma et al., 2017). However, the inbreeding nature, limited recombination rates and a historical genetic bottle-neck during isolated domestication of this crop significantly impacts the extent of available genetic diversity in finger millet. Such loss of genetic diversity is a challenge for geneticists and breeders working with a limited number of finger millet accessions. Further, until recently, there has been no progress in application of the finger millet genetic map in trait mapping despite the assembly of the only molecular marker-based linkage map a decade ago (Dida et al., 2007; Srinivasachary et al., 2007). It still remains under-utilized for tagging and identification of genes/quantitative trait locus (QTL) governing grain $\mathrm{Ca}$ content probably due to an insufficient number of informative markers.

The unavailability of sufficient markers and genome sequence information in finger millet has resulted in limited breeding efforts for nutritional improvement. Nonetheless, advances 
TABLE 2 | Modern finger millet varieties released in the last decade.

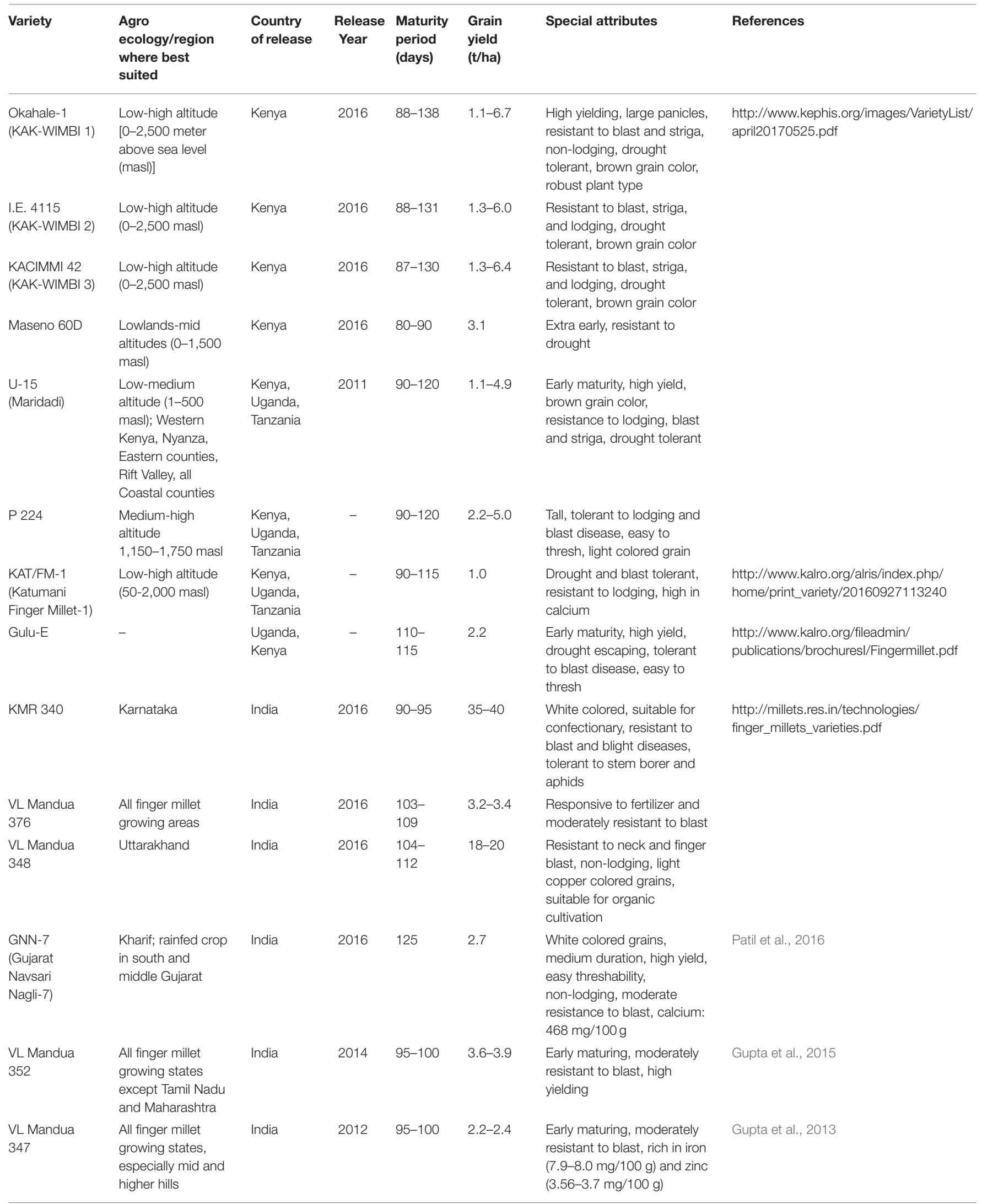


TABLE 2 | Continued

\begin{tabular}{|c|c|c|c|c|c|c|c|}
\hline Variety & $\begin{array}{l}\text { Agro } \\
\text { ecology/region } \\
\text { where best } \\
\text { suited }\end{array}$ & $\begin{array}{l}\text { Country } \\
\text { of release }\end{array}$ & $\begin{array}{l}\text { Release } \\
\text { Year }\end{array}$ & $\begin{array}{l}\text { Maturity } \\
\text { period } \\
\text { (days) }\end{array}$ & $\begin{array}{l}\text { Grain } \\
\text { yield } \\
\text { (t/ha) }\end{array}$ & Special attributes & References \\
\hline $\begin{array}{l}\text { INDIRA } \\
\text { RAGI-1 }\end{array}$ & $\begin{array}{l}\text { Suitable for early } \\
\text { monsoon } \\
\text { conditions in } \\
\text { Chattisgarh }\end{array}$ & India & 2012 & $\begin{array}{l}120- \\
125\end{array}$ & $2.8-2.9$ & $\begin{array}{l}\text { Semi dwarf, late maturity, } \\
\text { moderately resistant to neck } \\
\text { and finger blast and tolerant } \\
\text { to stem borer, Non } \\
\text { shattering, non-lodging and } \\
\text { responsive to fertilizers, } \\
\text { suitable for early monsoon } \\
\text { condition, can withstand } \\
\text { water stress }\end{array}$ & $\begin{array}{l}\text { http://www.dhan.org/smallmillets/docs/ } \\
\text { report/Compendium_of_Released_Varieties } \\
\text { _in_Small_millets.pdf }\end{array}$ \\
\hline $\begin{array}{l}\text { PPR } 2700 \\
\text { (NAKULA) }\end{array}$ & $\begin{array}{l}\text { Andhra Pradesh } \\
\text { region }\end{array}$ & India & 2012 & $\begin{array}{l}105- \\
110\end{array}$ & $2.8-3.3$ & $\begin{array}{l}\text { Semi dwarf plants, Medium } \\
\text { duration, Resistant to leaf } \\
\text { blast and drought tolerant }\end{array}$ & \\
\hline KMR 204 & Karnataka & India & 2012 & $\begin{array}{l}100- \\
105\end{array}$ & 3.3-3.9 & $\begin{array}{l}\text { Early duration and high } \\
\text { yielding }\end{array}$ & \\
\hline OEB 532 & $\begin{array}{l}\text { Odisha, Bihar, } \\
\text { Chattisgarh, } \\
\text { Karnataka, Tamil } \\
\text { Nadu }\end{array}$ & India & 2012 & $\begin{array}{l}110- \\
115\end{array}$ & $2.4-2.8$ & $\begin{array}{l}\text { Moderately resistant to blast } \\
\text { diseases, non- lodging and } \\
\text { non-shattering, highly } \\
\text { tolerant to myllocerus } \\
\text { weevil, earhead caterpillars, } \\
\text { stem borer and grass } \\
\text { hopper }\end{array}$ & \\
\hline OEB 526 & $\begin{array}{l}\text { Odisha, Bihar, } \\
\text { Chattisgarh, } \\
\text { Karnataka, } \\
\text { Tamilnadu }\end{array}$ & India & 2011 & $\begin{array}{l}110- \\
115\end{array}$ & $2.8-2.9$ & $\begin{array}{l}\text { Moderately resistant to leaf, } \\
\text { neck and finger blast } \\
\text { diseases, light brown } \\
\text { colored grains }\end{array}$ & \\
\hline $\begin{array}{l}\text { VR } 847 \\
\text { (Srichaitanya) }\end{array}$ & Andhra Pradesh & India & 2009 & $\begin{array}{l}110- \\
115\end{array}$ & $2.9-3.1$ & $\begin{array}{l}\text { Moderately resistant to } \\
\text { blast, tolerant to caterpillars } \\
\text { and aphids }\end{array}$ & \\
\hline $\begin{array}{l}\text { GN-5 (Gujarat } \\
\text { Nagli-5) }\end{array}$ & $\begin{array}{l}\text { Hilly area of south } \\
\text { Gujarat and middle } \\
\text { Gujarat region }\end{array}$ & India & 2009 & $\begin{array}{l}120- \\
130\end{array}$ & 3.4 & $\begin{array}{l}\text { White colored grains, high } \\
\text { yielding, easy to thresh, } \\
\text { non-lodging, moderately } \\
\text { resistant to leaf blast, } \\
\text { resistant to neck and finger } \\
\text { blast, non-lodging, calcium: } \\
432 \mathrm{mg} / 100 \mathrm{~g}\end{array}$ & Chaudhari et al., 2012 \\
\hline GPU 67 & $\begin{array}{l}\text { Widely adapted } \\
\text { across } \\
\text { Chattisgarh, } \\
\text { Jharkhand, } \\
\text { Karnataka, } \\
\text { Maharashtra, Tamil } \\
\text { Nadu and } \\
\text { Uttarakhand }\end{array}$ & India & 2009 & $\begin{array}{l}115- \\
120\end{array}$ & $4.4-5.0$ & $\begin{array}{l}\text { Semi dwarf, moderately } \\
\text { resistant to neck and finger } \\
\text { blast, calcium: } 219 \mathrm{mg} / 100 \\
\text { g, profuse tillering, copper } \\
\text { brown seeds }\end{array}$ & $\begin{array}{l}\text { http://www.dhan.org/smallmillets } \\
\text { /docs/report/Compendium_of_Released_ } \\
\text { Varieties_in_Small_millets.pdf } \\
\text { http://www.dhan.org/smallmillets } \\
\text { /docs/report/Compendium_of_Released } \\
\text { _Varieties_in_Small_millets.pdf } \\
\text { http://www.dhan.org/smallmillets } \\
\text { /docs/report//Compendium_of_Released } \\
\text { _Varieties_in_Small_millets.pdf }\end{array}$ \\
\hline GPU 66 & $\begin{array}{l}\text { Late kharif season } \\
\text { in Karnataka }\end{array}$ & India & 2009 & $\begin{array}{l}112- \\
115\end{array}$ & $3.9-4.4$ & $\begin{array}{l}\text { Resistant to neck and finger } \\
\text { blast }\end{array}$ & \\
\hline
\end{tabular}


TABLE 2 | Continued

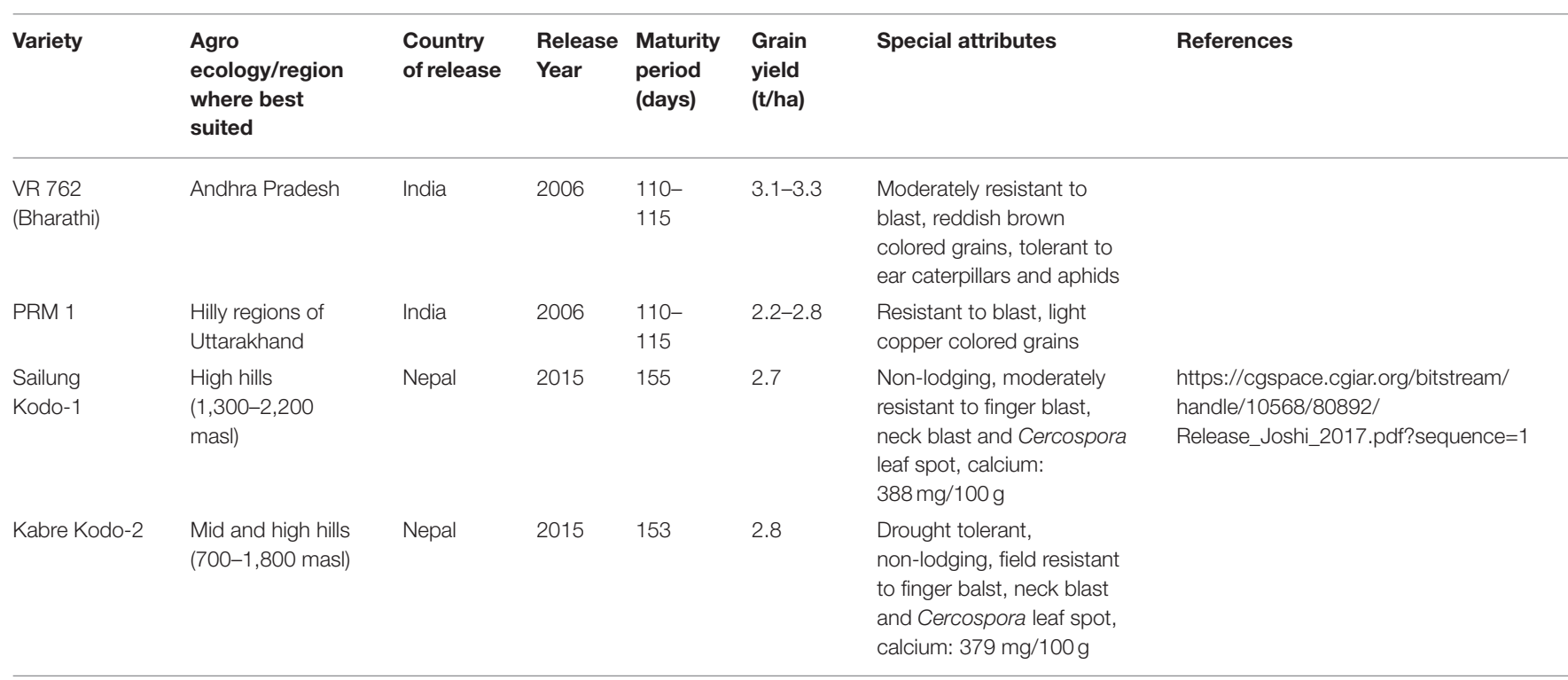

in large-scale genomics technology have now streamlined production of genome-wide markers which can be used for large-scale identification of candidate genomic loci. This advancement has also been capitalized to generate single nucleotide polymorphism (SNP) markers in finger millet using genotyping-by-sequencing (GBS; Kumar et al., 2016b) and Roche 454 and Illumina sequencing (Gimode et al., 2016). Inspite of the low level of polymorphisms in cultivated finger millet genotypes (Salimath et al., 1995), these SNPs may provide some explanation for variation in grain $\mathrm{Ca}$ content among finger millet genotypes. However, before their utilization, it is crucial to differentiate true SNPs among different genotypes from the homeologous SNPs within an individual genotype due to allotetraploidy (AA and $\mathrm{BB}$ sub-genomes) of finger millet.

Advances in cereal genomics have elaborated that genomic level similarities are conserved in the relative physical positions across species both on a fine scale (co-linearity) as well as on a chromosomal scale (synteny). For example, comparative mapping of finger millet to rice has shown a fairly high level of collinearity among these crops (Srinivasachary et al., 2007). The availability sequence information for several members of the grass family is now assisting in the development of inter-species molecular markers and gene discovery in unexplored crop genomes, such as finger millet (Wang et al., 2005; Kalyana Babu et al., 2014a,b). Until finger millet whole genome sequence becomes available, such comparative genomics approaches can benefit finger millet improvement programs. However, identification of common quantitative trait loci (QTLs) that control grain $\mathrm{Ca}$ content among cereals remains to be explored. This will further facilitate identification of orthologous regions and transfer of genetic information across species for improving $\mathrm{Ca}$ content of other millets and nonmillets.

\section{Inadequate Understanding of $\mathrm{Ca}$ Homeostasis Mechanisms in Finger Millet}

Emphasizing on the molecular status of $\mathrm{Ca}$ accumulation in finger millet grains, various genes have recently been identified (Sood et al., 2016). More recently, a molecular model for Ca transport from soil to seed has been proposed (Sharma et al., 2017). This hypothetical model is based upon genes that are differentially expressed in contrasting finger millet cultivars (Mirza et al., 2014) or grain filling and developing spike transcriptome studies in this crop (Singh et al., 2014, 2015; Kumar et al., 2015b). These genes correspond to Ca sensing and binding, $\mathrm{Ca}$ transport and seed storage, such as, type IIB ATPase, $\mathrm{Ca}^{2+} / \mathrm{H}^{+}$antiporter (CAX1), two pore channel (TPC1), calmodulin ( $C a M)$, CaM-dependent protein kinases (CaMK1 and CaMK2) and 14-3-3 (Table 3). High Ca accumulation in finger millet has been mainly attributed to the $\mathrm{Ca}$ sensor genes which have been proposed as candidates for targeted $\mathrm{Ca}$ enhancement in finger millet varieties (Singha et al., 2016). Alteration in the genes expression levels only indicates a pattern among the contrasting genotypes which does not always validate the translated protein products involved in $\mathrm{Ca}$ accumulation. A few recent studies have characterized accumulation of $\mathrm{Ca}$ binding protein (calreticulin) and CaM protein during grain filling stages of finger millet (Kumar et al., 2014; Singh et al., 2016). Unfortunately, large-scale protein profiling to identify the complete set of proteins involved in finger millet Ca homeostasis is still unavailable.

Even though the past and current developments have generated a huge wealth of transcriptomic datasets linked with the Ca uptake, translocation and accumulation in finger millet, without functional characterisation, these candidate genes are merely speculation. With a lack of evidence for efforts being made to functionally characterize these genes/proteins, it is possible that these potential candidates may not have expected 
TABLE 3 | List of important genes identified for calcium uptake, transport and storage in finger millet.

\begin{tabular}{|c|c|c|c|c|}
\hline Gene/Transcript & Tissue & Plant & Method & References \\
\hline \multicolumn{5}{|c|}{ CALCIUM SENSORS } \\
\hline $\begin{array}{l}\text { EcCaML8, } \\
\text { EcCaML11, } \\
\text { EcCaML14, } \\
\text { EcCaML18, } \\
\text { EcCaML29, } \\
\text { EcCaML35, } \\
\text { EcCaML38 }\end{array}$ & Developing Spike & $\begin{array}{l}\text { Genotypes GP-1 (low Ca } \\
\text { content) and GP- } 45 \text { (high Ca } \\
\text { content) }\end{array}$ & $\begin{array}{l}\text { Transcriptome analysis, } \\
\text { differential expression }\end{array}$ & Singh et al., 2014 \\
\hline $\begin{array}{l}\text { EcCBL2, } \\
\text { EcCBL4, } \\
\text { EcCBL6, } \\
\text { EcCBL9, } \\
\text { EcCBL10 }\end{array}$ & & & & \\
\hline \multicolumn{5}{|l|}{$\begin{array}{l}\text { EcCIPK5, } \\
\text { EcCIPK9, } \\
\text { EcCIPK11, } \\
\text { EcCIPK19, } \\
\text { EcCIPK24, } \\
\text { EcCIPK29, } \\
\text { EcCIPK31 }\end{array}$} \\
\hline \multicolumn{5}{|l|}{$\begin{array}{l}\text { EcCRK2, } \\
\text { EcCRK3 }\end{array}$} \\
\hline $\begin{array}{l}\text { EcCDPK4, } \\
\text { EcCDPK13, } \\
\text { EcCDPK17 }\end{array}$ & & & & \\
\hline
\end{tabular}

\section{CALCIUM UPTAKE AND TRANSLOCATION}

CAX1, TPC1, $\mathrm{Ca}^{2+}$

ATPase, CaMK1

CAX1, $\mathrm{Ca}^{2+}$ ATPase,

CaMK1, CaMK2

CAX1, 14-3-3, CAM

$\mathrm{CAX} 1, \mathrm{Ca}^{2+}$ ATPase,

CAM, CaMK2

CAM

CAX1, CAM, CaMK2

CAX1, TPC1, CAM,

CaMK2, 14-3-3

CALCIUM TRANSPORTERS

ECCAX4,

EcVCAX1a

EcVCX2,

EcCAX1b,

EcCAX3,

EcNaCa11exA,

EcNaCa11exB

EcPM8ATPase,

EcPM4ATPase8,

EcPM12ATPase,

EcPM2ATPase9,

EcPM1ATPasell,

EcPM12ATPase4,

EcPM5ATPase4,

EcPM3ATPaseB,

EcPM3ATPase2,

EcER3ATPase4,

EcER3ATPase3

ECCL1 pore
Genotypes GP-1 (low Ca

content) and GP-45 (high Ca

content)

Stem

Leaves

Spike:

inflorescence

immergence

Spike: anthesis

Spike: grain filling

Spike: grain

maturation

Developing Spike

Genotypes GP-1 (low Ca

content) and GP-45 (high $\mathrm{Ca}$

Transcriptome analysis,

differential expression
Differential expression

Mirza et al., 2014
Singh et al., 2015 
impact on enhancing grain Ca content. While, it is practically impossible to functionally characterize all genes linked with $\mathrm{Ca}$ acquisition, sensing and accumulation, transgenic technology along with progress in gene editing (such as CRISPR-Cas and TALEN) can aid in a better functional understanding of many candidate genes. Such advancements in gene editing technology along with well-established genetic transformation protocols for generation of transgenic finger millet (Kumar et al., 2016a) can significantly improve our understanding of this process.

Besides this, the role of other factors (for example, hormones, root morphological traits, endophytes, soil fertility, evapotranspiration pull, translocation distance of $\mathrm{Ca}$ ) on $\mathrm{Ca}$ homeostasis in finger millet remains unknown. This is a crucial question as the soil-plant interactions substantially affect the available proportion of micronutrient to the roots. In this context, soil medium supplemented with growth promoting rhizobacterium (Azotobacter, Azospirillium, phosphorus solubilizing bacteria) and vesicular-arbuscular mycorrhizal (VAM) fungi are generally practiced to enhance the grain yield and growth in finger millet (Ramakrishnan and Bhuvaneswari, 2014; Thilakarathna and Raizada, 2015). VAM are also known to increase the content and uptake of minerals, such as phosphate, nitrogen, zinc and copper (Tewari et al., 1993). The nutrient supply to the plant can be augmented either by efficiently mobilizing nutrient forms available in the soil or by extending the nutrient absorption surface by designing better roots system. However, how these associations impact $\mathrm{Ca}$ absorption and uptake in finger millet has received little experimental consideration. Further, the relationship between growth environments and climates may also alter xylem water flow, thus indirectly determining $\mathrm{Ca}$ distribution. So far, the established mechanisms of $\mathrm{Ca}$ accumulation in finger millet have been developed on the basis of controlled growth conditions. However, under field conditions, the unique soilroot interaction can influence the Ca-sensing and transport differently. In addition, any confounding effects of agronomic traits, such as vegetative growth, yield, stress resilience and disease resistance on grain $\mathrm{Ca}$ accumulation are not clearly established. Therefore, to develop finger millet as a model for Ca biofortification, we need a comprehensive understanding of the mechanisms and other factors that may influence this trait.

\section{Potential of Next Generation Sequencing (NGS) For Improved Finger Millet Varieties}

Enormous progress has been made in the genomics technology through application of high-throughput, economical and quicker next generation sequencing (NGS) platforms. Extending the benefits of NGS to finger millet, a recent effort of de novo sequencing has allowed whole genome sequence assembly covering approximately $82 \%$ of total estimated genome size (Hittalmani et al., 2017). Evidence of higher collinearity with foxtail millet and rice as compared to other Poaceae species, and the available genome sequencing information may help allele discovery and candidate gene identification for agronomically important traits (Hittalmani et al., 2017) leading to faster development of improved varieties. In addition, GBS, which is a NGS platform-based highly multiplexed genotyping system, has also been applied for SNP generation (Kumar et al., 2016b). Thus, now it is feasible to generate a higher density of markers by genotyping core collections of finger millet thereby increasing the level of genetic diversity explored. This is crucial for a predominantly self-fertilized crop like finger millet because it is expected to have low recombination rates and high linkage disequilibrium (LD) which would otherwise narrow the genetic diversity. Thus, the more genetically diverse populations in finger millet core collections, together with the huge amount of relevant marker information generated through NGS platforms can directly contribute to improved mapping resolution of traits, such as $\mathrm{Ca}$ content through genome-wide association studies (GWAS). By statistically reconnecting variation in grain Ca content back to its underlying genetic polymorphism, it is possible to identify functional common variants in LD and genomic regions where major-effect genes and QTLs (that serve as the targets of marker-assisted selection) are located. The GWAS studies can confirm previously identified genes involved in Ca homeostasis mechanisms as well as spot putative novel candidates. However, the efficiency of GWAS depends upon accurate grain $\mathrm{Ca}$ content phenotyping data over multilocation/multi-year trials.

An extension of MAS, genomic selection (GS) is an upcoming methodology in the area of genomics-assisted breeding (Meuwissen et al., 2001). In this approach, genomewide marker genotype data along with available phenotypic data for a tested (reference/training) population are used to predict the performance of an untested (breeding) population based on genomics estimated breeding values (GEBV). Thus, instead of identifying few large-effect loci associated with $\mathrm{Ca}$ content, the GEBV model can more accurately predict the expected phenotype of a broader breeding population. This significantly reduces the time and costs associated with phenotyping a trait like grain Ca content. Finger millet enjoys the availability of germplasm resources, such as the core collections, which can be utilized as test populations to build genomic prediction models. As GS eliminates the need for previous identification of major QTLs and their use in selection, it can substantially speed up the genetic gain in this "orphan" crop. Another advantage is that if GEBVs are efficiently evaluated, finger millet breeders can make appropriate selection choices even earlier in the program, thereby significantly saving time on the generation cycle (Heffner et al., 2010). However, the applicability of GS in finger millet and selection of superior genotypes are dependent upon precise measurement and heritability of $\mathrm{Ca}$ content, sufficient marker density, the extent of LD decay, effective design of training population and its genetic relationship with the breeding population (Varshney et al., 2014). Nevertheless, NGS can contribute in exploring the depth and breadth of genetic diversity across germplasm sets bringing forward a huge wealth of genetic information. This will eventually lead to a new horizon for finger millet $\mathrm{Ca}$ biofortification. 


\section{FUTURE PROSPECTS AND CONCLUSIONS}

By virtue of its health benefitting properties and environmental sustainability, a traditional but less popular crop like finger millet offers excellent opportunities for biofortification breeding. A foremost priority from geneticists and breeders viewpoint is capturing and utilizing genetic diversity for Ca content in the elite finger millet gene pools (for example, by bringing new sources of variation through rare and unique alleles). For trapping such useful variations, advances in the next generation sequencing technology must be utilized in generating sufficient number of markers for characterizing marker-trait associations and genomics-assisted breeding. With the implementation of such high-throughput approaches, it will be much easier to investigate the genetic architecture of this trait through comparative mapping in other millets and non-millet species. Mining of markers tightly linked to other traits governing grain Ca content and discovery of underlying genes can be an alternate strategy to develop high $\mathrm{Ca}$ finger millet varieties through traditional or modern breeding approaches and transformation-based methods. For example, rather than just arbitrarily increasing grain Ca content, future direction should target improvement in efficiency to mobilize, acquire, transport and store $\mathrm{Ca}$ in more bioavailable forms in the edible portions.

From the health perspective, at this point, we almost completely lack the understanding of interplay among grain $\mathrm{Ca}$, other micronutrients and antinutrients metabolism in human body. Any potential risks of reducing the antinutrient content in the grains should be evaluated with a view of their longterm effects on human health. Therefore, the focus should be on demonstrating finger millet's bio-efficacy in order to monitor any potential negative trade-offs and unintended effects. In addition, experimental confirmation of in vivo Ca bioavailability needs to be cautiously attempted through designing pilot feeding studies for vulnerable groups (like children, nursing or post-menopausal women). Although the biological effects of improved finger millet may be relatively modest, it will have potential benefits

\section{REFERENCES}

Agarwal, R., and Maheshwari, A. (2016). "Genetic improvement in the genus Eleusine," in Gene Pool Diversity and Crop Improvement, eds V. R. Rajpal, S. R. Rao, and S. N. Raina (Cham: Springer), 393-413.

Amalraj, A., and Pius, A. (2015). Influence of oxalate, phytate, tannin, dietary fiber and cooking on calcium bioavailability of commonly consumed cereals and millets in India. Cereal Chem. 92, 389-394. doi: 10.1094/CCHEM-11-14-0225-R

Antony, U., and Chandra, T. S. (1998). Antinutrient reduction and enhancement in protein, starch, and mineral availability in fermented flour of finger millet (Eleusine coracana). J. Agric. Food Chem. 46, 2578-2582. doi: 10.1021/jf9706639

Antony, U., and Chandra, T. S. (1999). Enzymatic treatment and use of starters for the nutrient enhancement in fermented flour of red and white varieties of finger millet (Eleusine coracana). J. Agric. Food Chem. 47, 2016-2019. doi: 10.1021/jf980564a

Asare-Marfo, D., Birol, E., Fiedler, J., Ha, B., Lividini, K., Moursi, M., et al. (2014). "Cost-effectiveness of biofortification," in The 2nd Global Conference in improving healthcare cost savings by reducing the risk of osteoporotic fractures and DALYs lost.

While agronomic factors can influence acceptability of the improved finger millet varieties by farmers, other parameters are important from the view of consumer acceptance. The extent of $\mathrm{Ca}$ recommended dietary allowance proportion as well as the sensory satisfaction supported by finger millet is essential in terms of developing food products keeping in line with recent lifestyle changes. Even after successful Ca biofortification of finger millet, its introduction and success as a functional food still entails knowledge of adequate food processing strategies (to minimize the nutrient loss) and study of consumer preferences. Further, communication support and the creation of market demand for its value-added products will be necessary. Therefore, a multi-disciplinary research approach, incorporating nutrition, health, agriculture, along with policy and market research, is needed to ensure the impact of high $\mathrm{Ca}$ biofortified finger millet. Overall, it is worthwhile to conclude that finger millet biofortification will improve the quality of life for both the rural subsistence farming families as well as the consumers.

\section{AUTHOR CONTRIBUTIONS}

SP and RY conceptualized the manuscript. SP wrote the manuscript. JK, PS, HO, and RY assisted and edited the manuscript. SP, JK, PS, and RS contributed in critically revising the draft and updating the manuscript for publication.

\section{ACKNOWLEDGMENTS}

The authors wish to express their thanks to IBERS, UK for the support in writing this manuscript. IBERS receives strategic funding from BBSRC. SP acknowledges Marie SkłodowskaCurie Individual Fellowship from Horizon 2020 of European Commission (Project 657331; CaMILLET). We would also like to acknowledge the editor and reviewers whose constructive comments and suggestions helped to improve the manuscript. on Biofortification: Getting Nutritious Foods to People. March 31-April 2, 2014 (Kigali).

Barbeau, W. E., and Hilu, K. W. (1993). Protein, calcium, iron, and amino acid content of selected wild and domesticated cultivars of finger millet. Plant Foods Hum. Nutr. 43, 97-104. doi: 10.1007/BF01087914

Baye, K. (2014). Teff: nutrient composition and health benefits. International Food Policy Research Institute (IFPRI) and Ethiopian Development Research Institute (EDRI). Washington, DC: Addis Ababa, Ethiopia

Bhide, R., Patil, S., Shetty, S., and Narayanan, S. (2013). Comparative bioavailability studies of calcium from different sources. Asian J. Pharm. Clin. Res. 6, 147-148.

Bolland, M. J., Avenell, A., Baron, J. A., Grey, A., MacLennan, G. S., Gamble, G. D., et al. (2010). Effect of calcium supplements on risk of myocardial infarction and cardiovascular events: meta-analysis. BMJ 341:c3691. doi: 10.1136/bmj.c3691

Bouis, H. E., Hotz, C., McClafferty, B., Meenakshi, J. V., and Pfeiffer, W. H. (2011). Biofortification: a new tool to reduce micronutrient malnutrition. Food Nutr. Bull. 32, S31-S40. doi: 10.1177/15648265110321s105

Carbonell-Capella, J. M., Buniowska, M., Barba, F. J., Esteve, M. J., and Frígola, A. (2014). Analytical methods for determining bioavailability and bioaccessibility 
of bioactive compounds from fruits and vegetables: a review. Compr. Rev. Food Sci. Food Saf. 13, 155-171. doi: 10.1111/1541-4337.12049

Chandrashekhar, H., Jayarame, G., and Jayashree, U. (2012). Formation of core set in Indian and African finger millet [Eleusine coracana (L.) Gaertn] germplasm accessions. Indian J. Genet.Plant Breed. 72, 358-363.

Chaudhari, P. P., Patel, D. A., Saravaiya, S. N., and Patel, M. C. (2012). GN-5: a new high yielding white grain finger millet variety. Int. J. Plant Sci. 7, 51-53.

Consensus Development Statement (1997). Who are candidates for prevention and treatment for osteoporosis? Osteoporos. Int. 7, 1-6. doi: 10.1007/BF01623453

Cook, J. D., Dassenko, S. A., and Whittaker, P. (1991). Calcium supplementation: effect on iron absorption. Am. J. Clin. Nutr. 53, 106-111.

Curry, A. (2013). Archaeology: the milk revolution. When a single genetic mutation first let ancient Europeans drink milk, it set the stage for a continental upheaval. Nature 500, 20-22 doi: 10.1038/500020a

Devi, P. B., Vijayabharathi, R., Sathyabama, S., Malleshi, N. G., and Priyadarisini, V. B. (2014). Health benefits of finger millet (Eleusine coracana L.) polyphenols and dietary fiber: a review. J. Food Sci. Technol. 51, 1021-1040. doi: 10.1007/s13197-011-0584-9

Dida, M. M., Srinivasachary, R. S., Bennetzen, J. L., Gale, M. D., and Devos, K. M. (2007). The genetic map of finger millet, Eleusine coracana. Theor. Appl. Genet. 114, 321-332. doi: 10.1007/s00122-006-0435-7

Dwivedi, S. L., Upadhyaya, H. D., and Gowda, C. L. L. (2009). Approaches to Enhance the Value of Genetic Resources in Crop Improvement. The FAO Regional Project "Capacity Building and Enhanced Regional Collaboration for the Conservation and Sustainable Use of Plant Genetic Resources in Asia." Available online at: http://www.fao.org/docrep/014/am265e00.pdf

Food and Agricultural Organization of the United Nations (2002). Human Vitamin and Mineral Requirements, Report of a joint FAO/WHO expert consultation, (Bangkok; Rome: FAO). Available online at: $\mathrm{ftp}: / / \mathrm{ftp}$.fao.org/docrep/fao/004/y2809e/y2809e00.pdf

Ganapathy, K. N. (2017). "Improvement in finger millet: status and future prospects," in Millets and Sorghum: Biology and Genetic Improvement. ed. J. V. Patil (Chichester, UK: John Wiley and Sons), 87-111.

Gao, X., LaValley, M. P., and Tucker, K. L. (2005). Prospective studies of dairy product and calcium intakes and prostate cancer risk: a meta-analysis. J. Natl. Cancer Inst. 97, 1768-1777. doi: 10.1093/jnci/dji402

Gibson, R. S., Bailey, K. B., Gibbs, M., and Ferguson, E. L. (2010). A review of phytate, iron, zinc, and calcium concentrations in plant-based complementary foods used in low-income countries and implications for bioavailability. Food Nutr. Bull. 31, S134-S146. doi: 10.1177/15648265100312s206

Gimode, D., Odeny, D. A., de Villiers, E. P., Wanyonyi, S., Dida, M. M., Mneney, E. E., et al. (2016). Identification of SNP and SSR markers in finger millet using next generation sequencing technologies. PLoS ONE 11:e0159437. doi: 10.1371 /journal.pone. 0159437

Giri, K. V. (1940). The availability of calcium and phosphorus in cereals. Indian J. Med. Res. 28, 101-111.

Goodman, M. T., Wu, A. H., Tung, K. H., McDuffie, K., Kolonel, L. N., Nomura, A. M., et al. (2002). Association of dairy products, lactose, and calcium with the risk of ovarian cancer. Am. J. Epidemiol. 156, 148-157. doi: 10.1093/aje/kwf022

Gull, A., Jan, A., Nayik, G. A., Prasad, K., and Kumar, P. (2014). Significance of finger millet in nutrition, health and value added products: a review. J. Environ. Sci. Comput. Sci. Eng. Technol. 3, 1601-1608.

Gupta, A., Agrawal, P. K., Bhatt, J. C., Sood, S., Pandey, B. M., and Joshi, D. (2013). Finger millet variety VL Mandua 347. Indian J. Genet. 73:120.

Gupta, A., Sood, A., Khulbe, R. K., Agrawal, P. K., Bhatt, J. C., and Pandey, B. M., et al. (2015). Finger millet Variety VL Mandua 352. Indian J. Genet. Plant Breed. $75: 153$.

Gupta, S. C., Muza, F. R., and Andrews, D. J. (1997). Registration of INFM 95001 finger millet genetic male-sterile line. Crop Sci. 37, 1409. doi: 10.2135/cropsci1997.0011183X003700040097x

Gupta, S. M., Arora, S., Mirza, N., Pande, A., Lata, C., Puranik, S., et al. (2017). Finger millet: a "certain" crop for an "uncertain" future and a solution to food insecurity and hidden hunger under stressful environments. Front. Plant Sci. 8:643. doi: $10.3389 /$ fpls.2017.00643

Haldipur, V. (2003). Boning Up On Osteoporosis. India Times. Nov 29, 2003. Available online at: http://timesofindia.indiatimes.com/bombay-times/ Boning-up-on-osteoporosis/articleshow/329075.cms
Harinarayana, G. (1986). "Breeding and varietal improvement of small millets in India," in Proceedings of the First International Small Millets Workshop Bangalore, India, October 29-November 2. ed A. Seetharam, K. W. Riley, and G. Harinarayana (New Delhi: Oxford \& IBH Publishing Co. Pvt. Ltd.).

Heaney, R. P. (2006). "The Calcium economy," in Calcium in Human Health, eds C. M. Weaver and R. P. Heaney (Totowa, NJ: Humana Press Inc.), 145-162.

Heffner, E. L., Lorenz, A. J., Jannink, J. L., and Sorrells, M. E. (2010). Plant breeding with genomic selection: gain per unit time and cost. Crop Sci. 50, 1681-1690. doi: 10.2135/cropsci2009.11.0662

Hemanalini, G., Umapathy, K. P., Rao, J. R., and Saraswathi, G. (1980). Nutritional evaluation of sprouted ragi. Nutr. Rep. Int. 22, 271-277.

Hittalmani, S., Mahesh, H. B., Shirke, M. D., Biradar, H., Uday, G., Aruna, Y. R., et al. (2017). Genome and transcriptome sequence of finger millet (Eleusine coracana (L.) Gaertn.) provides insights into drought tolerance and nutraceutical properties. BMC Genomics. 18:465. doi: $10.1186 / \mathrm{s} 12864-017-3850-\mathrm{z}$

Hotz, C., and Gibson, R. S. (2007). Traditional food-processing and preparation practices to enhance the bioavailability of micronutrients in plant-based diets. J. Nutr. 37, 1097-1100.

Institute of Medicine (US) Standing Committee on the Scientific Evaluation of Dietary Reference Intakes (1997). Dietary Reference Intakes for Calcium, Phosphorus, Magnesium, Vitamin D, and Fluoride. Washington, DC: National Academies Press.

Institute of Medicine (US) Committee to Review Dietary Reference Intakes for Vitamin D and Calcium (2011). Dietary Reference Intakes for Calcium and Vitamin D. eds A. C. Ross, C. L. Taylor, A. L. Yaktine, and H. B. Del Valle (Washington DC: National Academies Press).

Joseph, K., Kurien, P. P., Swaminathan, M., and Subrahmanyan, V. (1959). The metabolism of nitrogen, calcium and phosphorus in undernourished children. $\mathrm{V}$. The effect of partial or complete replacement of rice in poor vegetarian diets by ragi (Eleusine coracana) on the metabolism on nitrogen, calcium and phosphorus. Br. J. Nutr. 13, 213-218. doi: 10.1079/BJN19590028

Kalyana Babu, B., Dinesh, P., Agrawal, P. K., Sood, S., Chandrashekara, C., Bhatt, J. C., et al. (2014a). Comparative genomics and association mapping approaches for blast resistant genes in finger millet using SSRs. PLoS ONE 9:e99182; doi: 10.1371/journal.pone.0099182

Kalyana Babu, B., Pandey, D., Agrawal, P. K., Sood, S., and Kumar, A. (2014b). In silico mining, type and frequency analysis of genic microsatellites of finger millet (Eleusine coracana (L.) Gaertn.): a comparative genomic analysis of NBS-LRR regions of finger millet with rice. Mol. Biol. Rep. 41, 3081-3090. doi: 10.1007/s11033-014-3168-8

Kam, J., Puranik, S., Yadav, R., Manwaring, H. R., Pierre, S., Srivastava, R. K., et al. (2016). Dietary interventions for type 2 diabetes: how millet comes to help. Front. Plant Sci. 7:1454. doi: 10.3389/fpls.2016.01454

Kamchan, A., Puwastien, P., Sirichakwal, P. P., and Kongkachuichai, R. (2004). In vitro calcium bioavailability of vegetables, legumes and seeds. J. Food Compos. Anal. 17, 311-320. doi: 10.1016/j.jfca.2004.03.002

Kennefick, S., and Cashman, K. D. (2000). Inhibitory effect of wheat fibre extract on calcium absorption in Caco-2 cells: evidence for a role of associated phytate rather than fibre per se. Eur. J. Nutr. 39, 12-27. doi: 10.1007/s003940050071

Krishnan, R., Dharmaraj, U., and Malleshi, N. G. (2012). Influence of decortication, popping and malting on bioaccessibility of calcium, iron and zinc in finger millet. LWT-Food Sci. Technol. 48, 169-174. doi: 10.1016/j.lwt.2012.03.003

Krishnappa, M., Ramesh, S., Chandraprakash, J., Gowda, J., Bharathi, and Doss, D. D. (2009). Breeding potential of selected crosses for genetic improvement of finger millet. SAT eJournal. 7

Kumar, A., Metwal, M., Kaur, S., Gupta, A. K., Puranik, S., Singh, S., et al. (2016a). Nutraceutical value of finger millet [Eleusine coracana (L.) Gaertn.], and their improvement using omics approaches. Front. Plant Sci. 7:00934. doi: 10.3389/fpls.2016.00934

Kumar, A., Gaur, V. S., Goel, A., and Gupta, A. K. (2015b). De Novo assembly and characterization of developing spikes transcriptome of finger millet (Eleusine coracana): a minor crop having nutraceutical properties. Plant Mol. Biol. Rep. 33, 905-922. doi: 10.1007/s11105-014-0802-5

Kumar, A., Mirza, N., Charan, T., Sharma, N., and Gaur, V. S. (2014). Isolation, characterization and immunolocalization of a seed dominant CaM from finger millet (Eleusine coracana L. Gartn.) for studying its functional role 
in differential accumulation of calcium in developing grains. Appl. Biochem. Biotechnol. 172, 2955. doi: 10.1007/s12010-013-0714-0

Kumar, A., Yadav, S., Panwar, P., Gaur, V. S., and Sood, S. (2015a). Identification of anchored simple sequence repeat markers associated with calcium content in finger millet (Eleusine coracana). Proc. Natl. Acad. Sci. India. 85, 311-317. doi: 10.1007/s40011-013-0296-1

Kumar, A., Sharma, D., Tiwari, A., Jaiswal, J. P., Singh, N. K., and Sood, S. (2016b). Genotyping-by-sequencing analysis for determining population structure of finger millet germplasm of diverse origins. Plant Genome. 9, 1-15. doi: 10.3835/plantgenome2015.07.0058

Kumssa, D. B., Joy, E. J. M., Ander, E. L., Watts, M. J., Young, S. D., Walker, S., et al. (2015). Dietary calcium and zinc deficiency risks are decreasing but remain prevalent. Scientific Rep. 5:10974. doi: 10.1038/srep10974

Levy, J., Gavin, J. R., and Sowers, J. R. (1994). Diabetes mellitus: a disease of abnormal cellular calcium metabolism? Am. J. Med. 96, 260-273. doi: 10.1016/0002-9343(94)90152-X

Lin, J., Manson, J. E., Lee, I. M., Cook, N. R., Buring, J. E., and Zhang, S. M. (2007). Intakes of calcium and vitamin $\mathrm{D}$ and breast cancer risk in women. Arch. Intern. Med. 167, 1050-1059. doi: 10.1001/archinte.167.10.1050

Lindsay, R., Silverman, S. L., Cooper, C., Hanley, D. A., Barton, I., Broy, S. B., et al. (2001). Risk of new vertebral fracture in the year following a fracture. JAMA 285, 320-323. doi: 10.1001/jama.285.3.320

Lucarini, M., Canali, R., Cappelloni, M., Lullo, G. D., and Lombardi-Boccia, G. (1999). In vitro calcium availability from Brassica vegetables (Brassica oleracea L.) and as consumed in composite dishes. Food Chem. 64, 519-523. doi: 10.1016/S0308-8146(98)00159-9

Ma, L., Oei, L., Jiang, L., Estrada, K., Chen, H., Wang, Z., et al. (2012). Association between bone mineral density and type 2 diabetes mellitus: a meta-analysis of observational studies. Eur. J. Epidemiol. 27, 319-332. doi: 10.1007/s10654-012-9674-x

Mahmood, S., Ali, H., Ahmad, F., and Iqbal, Z. (2014). Estimation of tannins in different sorghum varieties and their effects on nutrient digestibility and absorption of some minerals in caged white leghorn layers. Int. J. Agri. Biol. $16,217-221$

Makokha, A. O., Oniang'o, R. K., Njoroge, S. M., and Kamar, O. K. (2002). Effect of traditional fermentation and malting on phytic acid and mineral availability from sorghum (Sorghum bicolor) and finger millet (Eleusine coracana) grain varieties grown in Kenya. Food Nutr. Bull. 23, 241-245.

Manwaring, H. R., Bligh, H. F. J., and Yadav, R. (2016). The challenges and opportunities associated with biofortification of pearl millet (Pennisetum glaucum) with elevated levels of grain iron and zinc. Front. Plant Sci. 7:1944. doi: $10.3389 /$ fpls.2016.01944

Mbithi-Mwikya, S., Camp, J. V., Yiru, Y., and Huyghebaert, A. (2000). Nutrient and antinutrient changes in finger millet (Eleusine coracan) during sprouting. Lebensm.Wiss. Technol. 33, 9-14. doi: 10.1006/fstl.1999.0605

McCance, R. A., and Widdowson, E. M. (1942). Mineral metabolism of healthy adults on white and brown bread dietaries. J. Physiol. 101, 44-85. doi: 10.1113/jphysiol.1942.sp003967

McKevith, B. (2004). Nutritional Aspects of Cereals. London: British Nutrition Foundation.

Meuwissen, T. H. E., Hayes, B. J., and Goddard, M. E. (2001). Prediction of total genetic value using genome-wide dense marker maps. Genetics 157,1819-1829.

Michaelsson, K. (2009). The calcium quandary. Nutrition 25, 655-656. doi: 10.1016/j.nut.2009.01.005

Michaelsson, K., Melhus, H., Ferm, H., Ahlbom, A., and Pedersen, N. L. (2005). Genetic liability to fractures in the elderly. Arch. Intern. Med. 165, 1825-1830. doi: $10.1001 /$ archinte.165.16.1825

Mirza, N., Taj, G., Arora, S., and Kumar, A. (2014). Transcriptional expression analysis of genes involved in regulation of calcium translocation and storage in finger millet [Eleusine coracana (L.) Gartn.]. Gene 550, 171-179. doi: 10.1016/j.gene.2014.08.005

Muthamilarasan, M., Dhaka, A., Yadav, R., and Prasad, M. (2016). Exploration of millet models for developing nutrient rich graminaceous crops. Plant Sci. 242, 89-97. doi: 10.1016/j.plantsci.2015.08.023

Nass, L. L., Sigrist, M. S., Ribeiro, C. S. d. C., and Reifschneider, F. J. B. (2012). Genetic resources: the basis for sustainable and competitive plant breeding. Crop Breed. Appl. Biotech. S2, 75-86. doi: 10.1590/S1984-70332012000500009
National Research Council (1996). Lost Crops of Africa: Grains, Vol. I. Washington, DC: The National Academies Press.

Nirgude, M., Babu, B. K., Shambhavi, Y., Singh, U. M., Upadhyaya, H. D., and Kumar, A. (2014). Development and molecular characterization of genic molecular markers for grain protein and calcium content in finger millet (Eleusine coracana (L.) Gaertn.). Mol. Biol. Rep. 41, 1189-1200. doi: $10.1007 / \mathrm{s} 11033-013-2825-7$

Nordin, B. E. C. (1976). "Nutritional considerations," in Calcium, Phosphate and Magnesium Metabolism, ed B. E. C. Nordin (Edinburgh: Churchill Livingstone), $1-35$.

Nordin, B. E. C. (1997). Calcium in health and disease. Food Nutr. Agr. 20, 13-26. Oei, L., Zillikens, M. C., Dehghan, A., Buitendijk, G. H. S., Casta-o-Betancourt, M. C., Estrada, K., et al. (2013). High bone mineral density and fracture risk in type 2 diabetes as skeletal complications of inadequate glucose control: the Rotterdam study. Diabetes Care 36, 1619-1628. doi: 10.2337/dc12-1188

O'Kennedy, M. M., Grootboom, A., and Shewry, P. R. (2006). Harnessing sorghum and millet biotechnology for food and health. J. Cereal Sci. 44, 224-235. doi: $10.1016 /$ j.jcs.2006.08.001

Padulosi, S., Mal, B., King, O. I., and Gotor, E. (2015). Minor millets as a central element for sustainably enhanced incomes, empowerment, and nutrition in rural india. Sustainability 7, 8904-8933. doi: 10.3390/su7078904

Panwar, P., Nath, M., Yadav, V. K., and Kumar, A. (2010). Comparative evaluation of genetic diversity using RAPD, SSR and cytochome P450 gene based markers with respect to calcium content in finger millet (Eleusine coracana (L.) Gaertn.). J. Genet. 89, 121-133. doi: 10.1007/s12041-010-0052-8

Parashuram, P. D., Gowda, J., Satish, R. G., and Mallikarjun, N. M. (2011). Heterosis and combining ability studies for yield and yield attributing characters in finger millet (Eleusine coracana (L.) Geartn.). Electron. J. Plant Breed. 2, 494-500.

Parikh, S. J., and Yanovski, J. A. (2003). Calcium intake and adiposity. Am. J. Clin. Nutr. 77, 281-287.

Patil, H. E., Patel, J. V., Vavdiya, P. A., Naghera, Y. V., and Intwala, C. G. (2016). A high yielding white colored finger millet variety GNN-7 for cultivation in south and middle Gujarat. Int. J. Trop. Agri. 34, 1407-1411.

Pittas, A. G., Lau, J., Hu, F. B., and Dawson-Hughes, B. (2007). The role of Vitamin $\mathrm{D}$ and Calcium in type 2 diabetes. A systematic review and meta-analysis. $J$. Clin. Endocrinol. Metab. 92, 2017-2029. doi: 10.1210/jc.2007-0298

Platel, K., Eipeson, S. W., and Srinivasan, K. (2010). Bioaccessible mineral content of malted finger millet (Eleusine coracana), wheat (Triticum aestivum), and barley (Hordeum vulgare). J. Agric. Food Chem. 58, 8100-8103. doi: $10.1021 /$ jf100846e

Rachic, K. O., and Peters, L. R. V. (1977). The Eleusines: A Review of the World Literature. Manual. Hyderabad: International Crops Research Institute for the Semi-Arid Tropics.

Ramachandra, G., Virupaksha, T. K., and Shadaksharaswamy, M. (1977). Relationship between tannin levels and in vitro protein digestibility in finger millet (Eleusine coracana Gaertn.) J. Agric. Food Chem. 25, 1101-1104. doi: $10.1021 /$ jf60213a046

Ramakrishnan, K., and Bhuvaneswari, G. (2014). Effect of inoculation of am fungi and beneficial microorganisms on growth and nutrient uptake of Eleusine coracana (L.) Gaertn. (Finger millet). Int. Lett. Nat. Sci. 13, 59-69. doi: 10. 18052/www.scipress.com/ILNS.13.59

Rao, B. S. N., and Prabavathi, T. (1982). Tannin contents of food commonly used in India and its influences on inoziable iron. J. Sci. Food Agric. 33, 89-96. doi: $10.1002 /$ jsfa. 2740330116

Ravindran, G. (1991). Studies on millets: proximate composition, mineral composition and phytate and oxalate contents. Food Chem. 39, 99-107. doi: 10.1016/0308-8146(91)90088-6

Saleh, A. S. M., Zhang, Q., Chen, J., and Shen, Q. (2013). Millet grains: nutritional quality, processing, and potential health benefits. Comp. Rev. Food Sci. Food Saf. 12, 281-295. doi: 10.1111/1541-4337.12012

Salimath, S. S., de Oliveira, A. C., Godwin, I. D., and Bennetzen, J. L. (1995). Assessment of genome origins and genetic diversity in the genus Eleusine with DNA markers. Genome 38, 757-763. doi: 10.1139/g95-096

Sanwalka, N. J., Khadilkar, A. V., and Chiplonkar, S. A. (2011). Development of non-dairy, calcium rich vegetarian food products to improve calcium intake in vegetarian youth. Curr. Sci. 101, 657-663. 
Schulz, A. G., Van Amelsvoort, J. M., and Beynen, A. C. (1993). Dietary native resistant starch but not retrograded resistant starch raises magnesium and calcium absorption in rats. J. Nutr. 123, 1724-1731.

Seetharam, A. (2001). Annual Report 2000-01. All India Coordinated Small Millets Improvement Project, Bangalore. 1-28.

Sharma, D., Jamra, G., Singh, U. M., Sood, S., and Kumar, A. (2017). Calcium biofortification: three pronged molecular approaches for dissecting complex trait of calcium nutrition in finger millet (Eleusine coracana) for devising strategies of enrichment of food crops. Front. Plant Sci. 7:2028. doi: $10.3389 /$ fpls.2016.02028

Shobana, S., Krishnaswamy, K., Sudha, V., Malleshi, N. G., Anjana, R. M., Palaniappan, L., et al. (2013). Finger Millet (Ragi, Eleusine coracana L.): a review of its nutritional properties, processing, and plausible health benefits. Adv. Food Nutr. Res. 69, 1-39. doi: 10.1016/B978-0-12-410540-9.00001-6

Singh, M., Metwal, M., Kumar, V. A., and Kumar, A. (2016). Identification and molecular characterization of $48 \mathrm{kDa}$ calcium binding protein as calreticulin from finger millet (Eleusine coracana) using peptide mass finger printing and transcript profiling. J. Sci. Food Agric. 96, 672-679. doi: 10.1002/ jsfa.7139

Singh, P., and Raghuvanshi, R. S. (2012). Finger millet for food and nutritional security. Afr. J. Food Sci. 6, 77-84. doi: 10.5897/AJFSX10.010

Singh, U. M., Chandra, M., Shankhdhar, S. C., and Kumar, A. (2014). Transcriptome wide identification and validation of calcium sensor gene family in the developing spikes of finger millet genotypes for elucidating its role in grain calcium accumulation. PLOS ONE 9:e103963. doi: 10.1371/journal.pone.0103963

Singh, U. M., Metwal, M., Singh, M., Taj, G., and Kumar, A. (2015). Identification and characterization of calcium transporter gene family in finger millet in relation to grain calcium content. Gene 566, 37-46. doi: 10.1016/j.gene.2015.04.021

Singha, A. K., Singha, R., Subramania, R., Kumara, R., and Wankhede, D. P. (2016). Molecular approaches to understand nutritional potential of coarse cereals. Curr. Genomics 17, 177-192. doi: 10.2174/1389202917666160202 215308

Sood, S., Kumar, A., Kalyana Babu, B., Gaur, V. S., Pandey, D., Kant, L., et al. (2016). Gene Discovery and advances in finger millet [Eleusine coracana (L.) Gaertn.] genomics-an important nutri-cereal of future. Front. Plant Sci. 7:1634. doi: $10.3389 /$ fpls.2016.01634

Srinivasachary, A., Dida, M. M., and Gale, M. D., Devos, K. M. (2007). Comparative analyses reveal high levels of conserved colinearity between the finger millet and rice genomes. Theor. Appl. Genet. 115, 489-499. doi: 10.1007/s00122-007-0582-5

Sripriya, G., Antony, U., and Chandra, T. S. (1997). Changes in carbohydrate, free amino acids, organic acids, phytate and $\mathrm{HCl}$ extractability of minerals during germination and fermentation of finger millet (Eleusine coracana). Food Chem. 58, 345-350. doi: 10.1016/S0308-8146(96)00206-3

Stein, A., Meenakshi, J. V., Qaim, M., Nestel, P., Sachdev, H. P. S., and Bhutta, Z. A. (2005). "Analyzing the Health Benefits of biofortified staple crops by means of the disability-adjusted life years approach: a handbook focusing on iron, zinc and vitamin A," in International Food Policy Research Institute (IFPRI) and International Center for Tropical Agriculture (CIAT), (Washington, DC; Cali).

Subrahmanyan, V., Narayanarao, M., Ramarao, G., and Swaminathan, M. (1955). The metabolism of nitrogen, calcium and phosphorus in human adults on a poor vegetarian diet containing ragi (Eleusine coracana). Br. J. Nutr. 9, 350-357. doi: 10.1079/BJN19550049

Suma, R. C., Sheetal, G., Jyothi, L. A., and Prakash, J. (2007). Influence of phytin phosphorous and dietary fibre on in vitro iron and calcium bioavailability from rice flakes. Int. J. Food Sci. Nutr. 58, 637-643. doi: 10.1080/096374807013 95515

Tewari, L., Johri, B. N., and Tandon, S. M. (1993). Host genotype dependency and growth enhancing ability of VA-mycorrhizal fungi for Eleusine coracana (finger millet). World J. Microbiol. Biotechnol. 9, 191-195. doi: 10.1007/BF003 27835

Thilakarathna, M. S., and Raizada, M. N. (2015). A review of nutrient management studies involving finger millet in the semi-arid tropics of Asia and Africa. Agronomy 5, 262-290. doi: 10.3390/agronomy5030262
Upadhyaya, H. D. (2008). "Genotyping of composite collection of finger millet [Eleusine coracana (L.) Gaertn.]," in Generation Challenge Program: Cultivating Plant Diversity for the Resource Poor (Project abstract). Mexico: CIMMYT, $64-65$

Upadhyaya, H. D., Dwivedi, S. L., Sharma, S., Lalitha, N., Singh, S., Varshney, R., et al. (2014). Enhancement of the use and impact of germplasm in crop improvement. Plant Genet. Res. 12, S155-S159. doi: $10.1017 /$ S1479262114000458

Upadhyaya, H. D., Pundir, R. P. S., Hash, C. T., Hoisington, D., Chandra, S., Gowda, C. L. L., et al. (2005). "Genotyping Finger Millet Germplasmdeveloping Composite Collection," in Generation Challenge Program Review Meeting, (Rome).

Upadhyaya, H. D., Ramesh, S., Sharma, S., Singh, S. K., Varshney, S. K., Sarma, N. D. R. K., et al. (2011). Genetic diversity for grain nutrients contents in a core collection of finger millet (Eleusine coracana (L.) Gaertn.) germplasm. Field Crops Res. 121, 42-52. doi: 10.1016/j.fcr.2010.11.017

Vadivoo, A. S., Joseph, R., and Ganesan, N. M. (1998). Genetic variability and diversity for protein and calcium contents in finger millet (Eleusine coracana (L.) Gaertn) in relation to grain color. Plant Foods Hum. Nutr. 52, 353-364. doi: 10.1023/A:1008074002390

Varshney, R. K., Terauchi, R., and McCouch, S. R. (2014). Harvesting the promising fruits of genomics: applying genome sequencing technologies to crop breeding. PLoS Biol. 12:e1001883. doi: 10.1371/journal.pbio.1001883

Verma, V., and Patel, S. (2013). Value added products from nutri-cereals: finger millet (Eleusine coracana). Emir. J. Food Agric. 25, 169-176. doi: 10.9755/ejfa.v25i3.10764

Vestergaard, P. (2006). Discrepancies in bone mineral density and fracture risk in patients with type 1 and type 2 diabetes-a meta-analysis. Osteoporosis Int. 18, 427-444. doi: 10.1007/s00198-006-0253-4

Vetriventhan, M., Upadhyaya, H. D., Dwivedi, S. L., Pattanashetti, S. K., and Singh, S. K. (2015). "Finger and foxtail millets", in Genetic and Genomic Resources for Grain Cereals Improvement, eds M. Singh and H. D. Upadhyaya (Cambridge: Academic Press), 291-319.

Vijayalakshmi, D., Geetha, K., Gowda, J., Ravi, S. B., Padulosi, S., and Mal, B. (2010). Empowerment of women farmers through value addition on minor millets genetic resources: a case study in Karnataka. Indian J. Plant Genet. Resour. 23, 132-135.

Wang, M. L., Barkley, N. A., Yu, J. K., Dean, R. E., Newman, M. L., Sorrells, M. E., et al. (2005). Transfer of simple sequence repeat (SSR) markers from major cereal crops to minor grass species for germplasm characterization and evaluation. Plant Genet. Resour. 3, 45-57. doi: 10.1079/PGR200461

Wang, M., Yang, X., Wang, F., Li, R., Ning, H., Na, L., et al. (2013). Calciumdeficiency assessment and biomarker identification by an integrated urinary metabonomics analysis. BMC Med. 11:86. doi: 10.1186/1741-7015-11-86

World Health Organization Food and Agricultural Organization of the United Nations (WHO) (2006). "Micronutrient malnutrition: a public health problem," in Guidelines on Food Fortification with Micronutrients, eds L. Allen, B. de Benoist, O. Dary, and R. Hurrell (Geneva: WHO Press), 3-17.

Yadav, S., Gaur, V. S., Jaiswal, J. P., and Kumar, A. (2014). Simple sequence repeat (SSR) analysis in relation to calcium transport and signaling genes reveals transferability among grasses and a conserved behavior within finger millet genotypes. Plant Syst. Evol. 300, 1561-1568. doi: 10.1007/s00606-014-0982-3

Yoshida, T., Shinoda, S., and Nagata, M. (1983). Effect of age and dietary phytate on the availability of phytate and minerals in rats. Agri. Biol. Chem. 47, 2641-2644.

Conflict of Interest Statement: The authors declare that the research was conducted in the absence of any commercial or financial relationships that could be construed as a potential conflict of interest.

Copyright (C) 2017 Puranik, Kam, Sahu, Yadav, Srivastava, Ojulong and Yadav. This is an open-access article distributed under the terms of the Creative Commons Attribution License (CC BY). The use, distribution or reproduction in other forums is permitted, provided the original author(s) or licensor are credited and that the original publication in this journal is cited, in accordance with accepted academic practice. No use, distribution or reproduction is permitted which does not comply with these terms. 